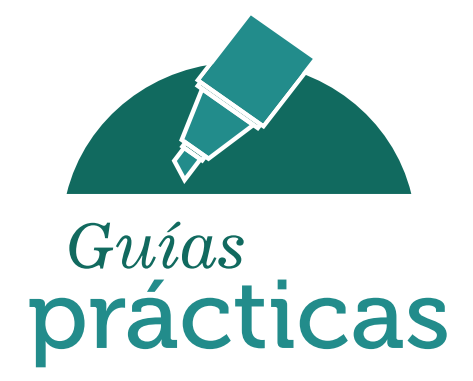

\title{
GUÍA DE CONSULTORIOS JURÍDICOS
}

Jorge Alfredo Gómez-Bautista Leidy Yobana Marin-Abadía

William Díaz-Cardona

Valerie Michel Vallejo-Vilaró

Diego Thomas Tavera-

Moncaleano

Germán Arturo Cardona-Villa

Andrés Fernando López-Cruz

Universidad Cooperativa de Colombia Sedes Pereira-Cartago 


\section{ACERCA DE LOS AUTORES}

Jorge Alfredo Gómez-Bautista. Candidato a magíster en Derecho con énfasis en Investigación. Profesor de tiempo completo, Universidad Cooperativa de Colombia.

Correo electrónico:

jorge.gomezb@campusucc.edu.co

Leidy Yobana Marin-Abadía. Especialista en Derecho Administrativo. Conciliadora y coordinadora del Consultorio Jurídico y Centro de Conciliación, Universidad Cooperativa de Colombia, sede Pereira-Cartago.

Correo electrónico:

leidy.marinab@ucc.edu.co

William Díaz-Cardona. Magíster en Educación. Conciliador y profesor de tiempo completo, Universidad Cooperativa de Colombia. Correo electrónico:

william.diaz@campusucc.edu.co

Valerie Michel Vallejo-Vilaró. Doctoranda en Derecho. Coordinadora de Investigaciones y profesora de tiempo completo, Facultad de Derecho, Universidad Cooperativa de Colombia, sede Cartago.

Correo electrónico:

valerie.vallejo@campusucc.edu.co

ORCID: 0000-0003-1324-2781
Diego Thomas Tavera-Moncaleano. Magíster en Prevención de Riesgos Laborales. Conciliador en derecho y profesor de tiempo completo, Universidad Cooperativa de Colombia. Correo electrónico: diego.taveram@campusucc.edu.co

Germán Arturo Cardona-Villa. Candidato a magíster en Propiedad Intelectual y Derechos de las Nuevas Tecnologías. Profesor de tiempo completo, Universidad Cooperativa de Colombia. Correo electrónico: german.cardona@campusucc.edu.co

Andrés Fernando López-Cruz. Magíster en Derecho Público y especialista en Derecho Laboral y Seguridad Social. Profesor de tiempo completo, Universidad Cooperativa de Colombia. Correo electrónico: andresf.lopezc@campusucc.edu.co

\section{CÓMO CITAR ESTE DOCUMENTO}

Gómez-Bautista, J. A., Marin-Abadía, L. Y., DíazCardona, W., Vallejo-Vilaró, V. M., Tavera-Moncaleano, D. T., Cardona-Villa, G. A. y López-Cruz, A. F. (2021). Guía de consultorios jurídicos (Generación de contenidos impresos $\left.\mathrm{N}^{\circ}{ }^{2} 22\right)$. Ediciones Universidad Cooperativa de Colombia. doi: https://doi.org/10.16925/gcgp.38

NOTA LEGAL

El presente documento de trabajo ha sido incluido dentro de nuestro repositorio institucional como Apropiación social de conocimiento por solicitud del autor, con fines informativos, educativos o académicos. Asimismo, los argumentos, datos y análisis incluidos en el texto son responsabilidad absoluta del autor y no representan la opinión del Fondo Editorial o de la Universidad.

DISCLAIMER

This coursework paper has been uploaded to our institutional repository as Social Appropriation of Knowledge due to the request of the author. This document should be used for informational, educational or academic purposes only. Arguments, data and analysis included in this document represent authors' opinion not the Press or the University.

c)(1) $($ Este documento puede ser consultado, descargado o reproducido desde nuestro repositorio institucional (http://repository. ucc.edu.co/handle/20.500.12494/7369) para uso de sus contenidos, bajo la licencia de Creative Commons Reconocimiento-NoComercial-SinObraDerivada 4.0 Internacional. http://creativecommons.org/licenses/by-nc-nd/4.0/ 


\section{TABLA DE CONTENIDO}

INTRODUCCIÓN

¿Quiénes pueden acceder al servicio del consultorio jurídico? $\quad 7$

Propósito de la guía

Objetivos del consultorio jurídico

Normatividad 8

Descripción del proceso por desarrollar en el consultorio 8

DERECHO ADMINISTRATIVO 10

$\begin{array}{ll}\text { Resumen } & 10\end{array}$

Introducción 11

Marco teórico 11

$\begin{array}{ll}\text { Actos administrativos } & 11\end{array}$

Definición de acto administrativo $\quad 11$

Elementos del acto $\quad 11$

Órgano competente 11

Declaración de voluntad administrativa 12

Término para interponer el recurso 13

Recurso de reposición $\quad 13$

Recurso de apelación 13

El silencio administrativo en los recursos 13

Modelo de recurso 15

$\begin{array}{ll}\text { PROCESOS POLICIVOS } & 18\end{array}$

$\begin{array}{ll}\text { Resumen } & 18\end{array}$

Introducción 19

Modelo de querella civil de policía $\quad 20$

PROCESOS EJECUTIVOS 25

Resumen 25

Introducción $\quad 26$

Modelo de poder ejecutivo singular $\quad 28$

Modelo de poder ejecutivo de alimentos $\quad 29$

Contrato de transacción 30

MASC: MÉTODOS ALTERNATIVOS DE SOLUCIÓN DE CONFLICTOS 31

$\begin{array}{ll}\text { Resumen } & 31\end{array}$

Introducción $\quad 32$ 
Los métodos alternativos de solución de conflictos (MASC) 32

La conciliación $\quad 33$

Elementos de la conciliación 33

Las ventajas de la conciliación $\quad 33$

Efectos de la conciliación $\quad 34$

El conciliador $\quad 34$

Obligaciones de los conciliadores $\quad 34$

Procedimiento conciliatorio 34

La audiencia de conciliación $\quad 35$

Referencias 36

LA ACCIÓN DE TUTELA 37

$\begin{array}{ll}\text { Resumen } & 37\end{array}$

Introducción 38

Conceptos y minuta de acción de tutela 38

Conceptos: acción de tutela e incidente de desacato 38

Características de la acción de tutela 38

Términos de la acción de tutela $\quad 40$

Consecuencias del incumplimiento de un fallo de tutela $\quad 40$

Requisitos de la acción de tutela $\quad 41$

Derecho de petición $\quad 41$

Términos del derecho de petición $\quad 42$

Requisitos del derecho de petición $\quad 43$

Referencias $\quad 43$

Minuta de acción de tutela $\quad 44$

$\begin{array}{ll}\text { Minuta de incidente de desacato } & 46\end{array}$

Minuta de derecho de petición 48

DERECHO DE FAMILIA

Resumen $\quad 50$

Introducción $\quad 51$

Conceptos en proceso de alimentos $\quad 51$

Demanda de alimentos $\quad 52$

Referencias $\quad 53$

DERECHO LABORAL Y SEGURIDAD SOCIAL 59

Resumen $\quad 59$

Introducción $\quad 60$

Conceptos y liquidaciones de derecho laboral individual y seguridad social 60

$\begin{array}{ll}\text { Conceptos generales } & 60\end{array}$ 
Concepto de derecho laboral y elementos del contrato de trabajo

Concepto de seguridad social desde la Constitución y desde la

Ley 100 de 1993

Componentes del Sistema Integral de Seguridad Social 61

Clases y modalidades del contrato de trabajo $\quad 62$

Según su forma (art. 37 CST) 62

Verbal (art. 38 CST) $\quad 62$

Escrito (art. 39 CST) 62

Tácito 63

Según su duración o modalidad (art. 45 CST) 63

Fijo (art. 46 cST y arts. 1 y 2 del Decreto 1127 de 1991) 63

Indefinido (art. 47 CST) 64

Contrato de obra o labor determinada (art. 45 CST) 65

Contrato ocasional o transitorio (art. 6 CST) 65

Salario 66

Concepto y salario mínimo $\quad 66$

Factores salariales y factores no salariales 66

Ejercicio sobre factores salariales $\quad 67$

Prestaciones sociales mínimas y derecho a vacaciones 67

Vacaciones (art. 186 y ss. del cST) 67

Forma de remuneración 68

Ejercicio práctico 68

Auxilio de transporte $\quad 69$

Dotación de calzado y vestido de labor (arts. 230 y ss. CST) 69

Auxilio de cesantías (arts. 249 y ss. CST) 69

Salario con que se realiza la liquidación $\quad 70$

$\begin{array}{ll}\text { Liquidación } & 70\end{array}$

$\begin{array}{ll}\text { Ejercicio } & 70\end{array}$

Prima de servicios (arts. 306 y ss. del cst) 71

Liquidación $\quad 71$

Intereses de cesantías Ley 52 de 1975

Forma, monto y plazo de pago $\quad 72$

$\begin{array}{ll}\text { Ejercicios prácticos } & 72\end{array}$

Primer caso hipotético $\quad 72$

Segundo caso hipotético: salarios variables en cada año 73

$\begin{array}{ll}\text { Referencias } & 75\end{array}$ 


\title{
22 GUÍA DE CONSULTORIOS
}

\author{
Jorge Alfredo Gómez-Bautista \\ Leidy Yobana Marin-Abadía \\ William Díaz-Cardona \\ Valerie Michel Vallejo-Vilaró \\ Diego Thomas Tavera-Moncaleano \\ Germán Arturo Cardona-Villa \\ Andrés Fernando López-Cruz
}

\begin{abstract}
Resumen
Esta guía tiene como propósito acompañar al estudiante en el desarrollo de competencias en diversas áreas del derecho, como lo son los métodos alternativos de solución de conflictos, el derecho penal, el derecho civil, el derecho de familia, el derecho laboral y el derecho público. De este modo, se busca brindar las herramientas necesarias que permitan garantizar una atención oportuna, de calidad y eficiente en los diferentes temas que nuestros usuarios puedan llegar a requerir. Es una base y punto de partida para continuar aplicando y desarrollando las competencias que durante todos estos años se han venido formando, mediante el planteamiento de soluciones jurídicas a los asuntos concretos requeridos.
\end{abstract}

Palabras clave: acto administrativo, contrato de trabajo, derecho laboral, liquidaciones laborales, prestaciones sociales, querella civil, recurso de apelación, recurso de reposición, seguridad social. 


\section{INTRODUCCIÓN}

Los consultorios jurídicos son uno de los últimos pasos que deben cumplir los estudiantes de derecho en Colombia para optar por el título profesional de abogado; sin embargo, estos no solo se convierten en un requisito más, sino que son la forma como se pretende concienciar a los futuros profesionales en la sensibilidad social que se debe tener en el desarrollado posterior al grado. Se trata de consolidar en el estudiante la conciencia de su compromiso con las personas que, al acceder a este sistema o, posteriormente, al acudir a un letrado en leyes, buscan no solo la solución de un conflicto, sino también generar tranquilidad para sí mismas y sus familias.

El consultorio jurídico se vuelve un eslabón importante en la formación de los profesionales, ya que permite conocer las diferentes herramientas en las aristas de las ramas del derecho, para generar de manera efectiva acceso a la justicia a personas con poder adquisitivo limitado.

La presente Guía de consultorios jurídicos tiene como propósito acompañar al estudiante en el desarrollo de competencias en diversas áreas del derecho, como lo son los métodos alternativos de solución de conflictos, el derecho penal, el derecho civil, el derecho de familia, el derecho laboral y el derecho público. De este modo, se busca brindar las herramientas necesarias que permitan garantizar una atención oportuna, de calidad y eficiente en los diferentes temas que nuestros usuarios puedan llegar a requerir. Es una base y punto de partida para continuar aplicando y desarrollando las competencias que durante todos estos años se han venido formando, mediante el planteamiento de soluciones jurídicas a los asuntos concretos requeridos.

La guía fue desarrollada por asesores y docentes de la Universidad Cooperativa de Colombia, Sede Pereira-Cartago, y está orientada a que nuestros estudiantes tengan una base funcional para continuar desarrollando las competencias que a lo largo de sus años de estudio han venido formando y que los enriquecerán como personas y profesionales.

\section{¿Quiénes pueden acceder al servicio del consultorio jurídico?}

Podrá ser usuario del consultorio jurídico cualquier persona natural de bajos recursos económicos o en condición vulnerable, para lo que deberá presentar fotocopia del último recibo de servicios públicos, donde se logre verificar a qué estrato socioeconómico pertenece; copia de carné o certifico de afiliación a salud del régimen subsidiado; fotocopia de certificación emitida por funcionario competente si se encuentra en condición de desplazado; o mediante certificación laboral que exponga que no devenga más de dos salarios mensuales.

\section{Propósito de la guía}

La presente guía tiene el propósito de brindar información relacionada con el servicio social de asesoría jurídica y promoción de mecanismos alternativos que aporten a la resolución de conflictos, en áreas de derecho público, laboral, penal y privado.

\section{Objetivos del consultorio jurídico}

El consultorio jurídico, en aras de complementar y reforzar los conocimientos adquiridos por el estudiante en formación, tiene como objetivo proyectar el pensamiento y la acción de la institución a través de su comunidad académica, promoviendo su interdisciplinariedad y su compromiso social. De igual forma, se tiene como objetivo el acceso eficaz a la administración de la justicia, fomentar los derechos 
fundamentales e incentivar a los estudiantes a participar como entes conciliadores en la solución de conflictos.

\section{Recomendaciones}

Se recomienda que los temas desarrollados en la presente guía no limiten el actuar del litigante, sino que sirvan como base para la investigación profunda, objetiva y reflexiva (contextualización) del conflicto. Todo conocimiento adquirido o experiencia relevante deberían ser difundidos a fin de que sirvan de apoyo en posteriores casos para la resolución de conflictos.

En cualquier caso, es necesario difundir y propender a la conciliación como alternativa extrajudicial para la solución de conflictos. Es igualmente fundamental servir a la comunidad como entes neutrales para que la solución del conflicto sea mucho más objetiva y coherente.

\section{Normatividad}

La Ley 583 de 2000 indica:

Los estudiantes adscritos a los consultorios jurídicos de las facultades de derecho son abogados de pobres y como tales deberán verificar la capacidad económica de los usuarios. En tal virtud, acompañarán la correspondiente autorización del consultorio jurídico a las respectivas actuaciones judiciales y administrativas. La prestación del servicio del consultorio jurídico en ningún caso será susceptible de omisión ni homologación.

Los estudiantes, mientras pertenezcan a dichos consultorios, podrán litigar en causa ajena en diversos asuntos, actuando como abogados de población de escasos recursos, en múltiples escenarios:

- Procesos penales que conocen los jueces municipales, los fiscales delegados ante estos, así como las autoridades de policía, en condición de apoderados de los implicados.

- Procesos penales de competencia de la jurisdicción ordinaria, como representantes de la parte civil.

- Procesos penales como voceros o defensores en audiencia (de oficio).

- Procesos laborales en que la cuantía de la pretensión no exceda los 20 salarios mínimos legales mensuales vigentes y en las diligencias administrativas de conciliación en materia laboral.

- Procesos civiles que conocen los jueces municipales en única instancia.

- Procesos de alimentos que se adelanten ante los jueces de familia.

- Procesos disciplinarios de competencia de las personerías municipales y la Procuraduría General de la Nación.

- Procesos de responsabilidad fiscal de competencia de las contralorías municipales, distritales y departamentales, y de la Contraloría General de la República.

- Procesos administrativos de carácter sancionatorio que adelanten las autoridades administrativas, los organismos de control y las entidades constitucionales autónomas (Ley 583 de 2000).

\section{Descripción del proceso por desarrollar en el consultorio}

1. El usuario se acerca al consultorio para exponer su caso.

2. El usuario se encarga de relatar los hechos, en tiempo (momento), modo (de qué manera ocurrieron) y lugar (dónde ocurrieron). 
3. El estudiante realiza el análisis de caso para ubicarlo en el debido proceso (civil, laboral, contencioso administrativo, etc.). Si se tiene alguna duda, el estudiante puede acudir a los asesores para recibir orientación.
4. Se solicita documentación pertinente de acuerdo con el caso expuesto y el proceso que se deba adelantar.

5. Se procede a realizar la actividad correspondiente, ya sea una demanda, una conciliación, etc. 


\section{DERECHO ADMINISTRATIVO}

Por Jorge Alfredo Gómez-Bautista

\section{Resumen}

Dentro del marco de las asesorías que llegan a los estudiantes de Consultorio Jurídico, encontramos trámites relacionados con sanciones administrativas, conflictos de servicios públicos domiciliarios, notificaciones de decisiones irregulares, entre muchas otras. Por esta razón, se justifica la necesidad de generar un espacio técnico y práctico, para que los practicantes puedan resolver diferentes inquietudes de los usuarios. En este capítulo se encuentran algunas directrices que permitirán al estudiante de Consultorio Jurídico llevar a cabo sus asesorías con mayor fluidez y facilidad.

Palabras clave: acto administrativo, elementos del acto, petición, recursos, sede administrativa. 


\section{INTRODUCCIÓN}

El desarrollo de asesorías o actuaciones jurídicas por parte de los estudiantes practicantes de consultorio jurídico se relacionan especialmente con la presentación de derechos de petición y de recursos de sede administrativa. Conocer la teoría del acto administrativo, los términos para resolver las solicitudes o peticiones, la oportunidad para presentar recursos u objetar decisiones son asuntos indispensables para el futuro profesional del derecho en ese inmenso marco de relaciones entre el Estado y el Particular.

\section{MARCO TEÓRICO}

\section{Actos administrativos}

\section{DEFINICIÓN DE ACTO ADMINISTRATIVO}

Según Rafael Bielsa (citado en Ridulfo y Herrera, 2018), "es la decisión general o especial de una autoridad administrativa, en el ejercicio de sus propias funciones, y que se refiere a derechos, deberes e intereses de las entidades administrativas o de los particulares respecto de ellas". Para comprender mejor el concepto, Lino Fernández señala:

La expresión actos administrativos está referida a la actividad del Estado que ejerce una de las funciones fundamentales como es la función administrativa, cuya manifestación de voluntad se traduce a través de un conjunto de actos de administración, para alcanzar sus fines políticos jurídicos, económicos y sociales. (citado en Ridulfo y Herrera, 2018)

El acto administrativo es la forma en la que el Estado se pronuncia respecto de sus intereses, y como tal manifiesta su voluntad, bajo los parámetros de legalidad y responsabilidad como principios fundamentales amparados en el debido proceso, baluarte constitucional. Es oportuno aclarar que la importancia de un buen análisis de un acto administrativo radica en el estudio de las causales de nulidad dispuestas en el artículo 137 del Código de Procedimiento Administrativo y de lo Contencioso Administrativo (CPACA).

\section{ELEMENTOS DEL ACTO}

El acto debe ser legal. La legalidad es la observancia de la ley, es decir, aquella que vincula la manifestación de voluntad de la administración, estableciendo un nexo de causalidad entre el resultado del acto y la norma de derecho. La primera condición de la legalidad es la competencia de la gente. Los elementos centrales son:

- Órgano competente

- Voluntad administrativa

- Contenido

- Motivos

- Forma

- Fin

\section{Órgano competente}

El acto debe emanar de la administración, es decir, de un órgano estatal que actúe en función administrativa. Además, el órgano de la administración debe actuar dentro de los límites de su competencia. Si los excede, el acto resulta viciado según sea la naturaleza del exceso cometido.

La palabra competencia significa 'atribución', 'potestad', 'facultad'; o, lo que es lo mismo, facultad que tiene el órgano estatal, dada por la ley, para conocer de determinados asuntos y decidir sobre ellos en razón de la materia, del 
territorio, del tiempo y del grado o lugar jerárquico que ocupe ese órgano dentro de la escala administrativa. De tal suerte, habrá incompetencia por esas mismas razones, es decir, por la materia, por el territorio, por el tiempo y por el grado o funcional, y esta es una causal de nulidad de los actos administrativos que está consagrada en el artículo 84 del Código Contencioso Administrativo, denominada vicio de incompetencia o abuso de poder.

\section{Declaración de voluntad administrativa}

Es la existencia de una voluntad estatal válida exteriorizada en una declaración expresada en forma legal. El acto administrativo se aprecia a través de esa declaración, pero lo esencial es la voluntad real del órgano administrativo. Las formas de expresión de la voluntad pueden ser expresas o tácitas.

\section{Contenido del acto administrativo}

Es el mismo objeto del acto administrativo, el cual debe ajustarse a todas las normas jurídicas vigentes. Es la relación jurídica que crea el contenido del acto, en forma tal que objeto y contenido aparecen identificados. Es el resultado práctico que el órgano se propone conseguir a través suyo. El contenido y el objeto deben ser lícitos, ciertos y posibles (es imposible cuando está prohibida por la ley). Debe ser lícito en cuanto debe respetar las garantías y derechos de las personas.

\section{Partes del contenido}

El contenido exige la concurrencia de varias formalidades que podemos llamar partes, son las siguientes: encabezamiento, preámbulo, motivación, parte dispositiva y firmas, como se muestra en la tabla 1.

TABLA 1

Parte del contenido de un acto administrativo

Parte

Encabezamiento

\begin{tabular}{|c|}
\hline Preámbulo \\
\hline
\end{tabular}

Motivación

\begin{tabular}{|l|} 
\\
\end{tabular}

Parte dispositiva

Firmas

\begin{tabular}{|c|}
\hline Firmas \\
\hline Motivo
\end{tabular}

\begin{tabular}{|c|} 
Forma \\
\hline Fin
\end{tabular}

Nota: elaboración propia.

\section{Descripción}

Es la parte que señala el órgano administrativo que va a expedir el acto. Se dirá entonces si se trata de decreto, resolución, acuerdo; luego se indicará la fecha de expedición del acto y, a continuación, el nombre del cargo del funcionario que lo expide.

Es aquella parte explicativa de las facultades legales que invoca el funcionario u órgano administrativo, con base en las cuales va a dictar el acto.

Es la exposición de los motivos o fundamentos de hecho y de derecho en los cuales se va a apoyar la decisión. Como regla general, en el derecho colombiano no se exige la motivación sino cuando una norma así lo disponga, como, por ejemplo, las sanciones disciplinarias, las aperturas de las licitaciones públicas, las adjudicaciones, las conclusiones de las actuaciones administrativas, los actos que resuelvan recursos, etc.

La motivación es distinta del motivo del acto. La motivación, en términos sencillos, son los considerandos. En cambio, el motivo es el antecedente de hecho y de derecho que impulsa a la administración a actuar para tomar una decisión. Lo anterior implica que no todos los actos llevan motivación, pero todos los actos administrativos deben tener como causa previa un motivo.

Es la decisión. Está precedida de las palabras DECRETA, RESUELVA o ACUERDA. Se divide en artículos y finaliza con la expresión dado en (Medellín, Bogotá, etc.), a los tantos días del mes de ... de tal año. Después de lo cual contiene una orden: notifíquese, comuníquese o publíquese y cúmplase de acuerdo con la índole del acto, es decir, si es general o particular y concreto.

y concreto.

nalmente, el acto lleva la firma del funcionario que lo ha expedido. En síntesis, el vicio de los motivos causa nulidad del acto por falsa motivación: en los fines, por desviación de poder; en el órgano competente, por abuso de poder; y en la forma por la expedición irregular.

Son los antecedentes de hecho o de derecho que impulsan a la administración a actuar, como se enunció anteriormente.

Cuando hablamos de forma en derecho administrativo, nos estamos refiriendo a si el acto administrativo es oral u escrito. Normalmente es escrito, con la excepción de los actos fictos o presuntos de que trata la parte primera del cPACA. La forma no debe confundirse con las formalidades, que son los pasos previos o exigencias que la ley hace para llegar a la forma y para que el acto sea válido, en los términos del CPACA. En otros términos, son los requisitos que han de observarse para dictar el acto que normalmente son anteriores, pero también pueden ser concomitantes o posteriores al acto

Es lo que se persigue con el acto. La finalidad del acto es la de realizar el interés que con él se persigue. Este fin debe coincidir con el que precisa la norma que da la competencia, porque de no ser así, se dará una desviación de poder. 


\section{Término para interponer el recurso}

El artículo 76 del CPACA establece que el término para interponer los recursos dentro del procedimiento administrativo en sede administrativa es de 10 días para la reposición y la apelación, y de 5 días para la queja.

\section{Recurso de reposición}

Es el que se promueve ante el mismo funcionario o entidad administrativa que profirió la providencia administrativa —no procede generalmente contra los actos de trámite, con el objeto de que se aclare, modifique o revoque, y en ocasiones es el único que puede plantearse por vía gubernativa, por no tener superior alguno el funcionario u órgano que dictó el acto, o por agotarse la vía gubernativa en dicho funcionario, por virtud de expresa disposición legal.

Esto no implica que sea obligatorio plantear este recurso antes que el jerárquico o de apelación; interponer dicho recurso es un derecho y como tal puede renunciarse, salvo que una norma legal diga lo contrario, evento en el cual sí será obligatorio. En nuestro derecho positivo, el recurso de reposición no es obligatorio interponerlo para el ejercicio de las acciones contenciosas administrativas, es decir, no obliga para agotar vía gubernativa.

\section{RECURSO DE APELACIÓN}

Este recurso, que procede ante el órgano superior inmediato, denominado generalmente jerárquico o de apelación, persigue los mismos objetivos del recurso de reposición: la aclaración, modificación o revocación del acto, y su fundamento es el mismo: razones de juridicidad o de conveniencia.

Salvo norma especial en contrario, el recurso de apelación no procede contra providencias proferidas por los ministros, jefes de departamentos administrativos, superintendentes y representantes legales de las entidades descentralizadas por servicios o Unidades Administrativas Especiales que tengan personería jurídica; por tanto, se agota la vía gubernativa en los mismos funcionarios con su pronunciamiento definitivo o con la interposición y decisión expresa o ficta del recurso de reposición en los casos en que proceda. Desde luego que si hay norma que diga que procede recurso de apelación ante un ministro o jefe de departamento administrativo, por ser especial, se aplicará.

\section{EL SILENCIO ADMINISTRATIVO EN LOS RECURSOS}

Cuando ha transcurrido un plazo de dos (2) meses contados a partir de la interposición de los recursos de reposición o apelación sin que se haya notificado decisión expresa sobre ellos, se entenderá que la decisión es negativa (artículo 86 CPACA). El plazo mencionado se interrumpe en el evento de que se hayan solicitado pruebas al interponer el recurso respectivo y mientras dure la práctica de ellas.

Ejercitado el recurso pertinente, es decir, reposición, o reposición y subsidiariamente apelación, o directamente el de apelación, y transcurridos, como hemos visto, dos meses (2) calendario desde la fecha de presentación del recurso, descontados los términos de interrupción por la práctica de pruebas o por razón del incidente de impedimento o recusación del funcionario, sin que la autoridad haya notificado al recurrente decisión expresa sobre ellos, se entenderá que hay acto administrativo presunto o ficto negativo que niega el recurso o recursos, en el evento de que el interesado, haciendo uso del silencio, decida llevar la contención a la jurisdicción especial de lo contencioso administrativo. 


\section{REFERENCIAS}

Asamblea Nacional Constituyente. (2020). Constitución Política de Colombia. http://www.secretariasenado.gov. co/senado/basedoc/constitucion_politica_1991.html

Congreso de la República de Colombia. (2019). Ley 1437 de 2011. Código de Procedimiento Administrativo de lo Contencioso Administrativo. http://www.secretariasenado.gov.co/senado/basedoc/ley_1437_2011.html

Congreso de la República de Colombia. (2019). Ley 489 de 1998. Organización del Estado Colombiano http:// www.secretariasenado.gov.co/senado/basedoc/ley_0489_1998.html

Congreso de la República de Colombia. (2019). Ley 80 de 1993: Estatuto de Contratación Pública. http://www. secretariasenado.gov.co/senado/basedoc/ley_0080_1993.html

Parejo Alfonso, L. (2011). Lecciones de derecho administrativo. Bogotá: Universidad Externado de Colombia.

Peirano Facio, J. (2004). Responsabilidad extracontractual. Temis.

Rodríguez Rodríguez, L. (2015). Derecho administrativo: general y colombiano. Temis.

Rodríguez, L. (2015). Estructura del poder público en Colombia. Temis.

Ruiz Orejuela, W. (2013). Responsabilidad del Estado y sus Regímenes. Ecoe Ediciones.

Vidal Perdomo, J. y Molina Betancur, C. (2016). Derecho administrativo. Legis.

Younes Moreno, D. (2007). Curso de derecho administrativo. Temis.

Younes Moreno, D. (2013). Derecho administrativo laboral: régimen de los servidores públicos en Colombia. Temis. 


\section{MODELO DE RECURSO}

Señor:

E. S. M.

\section{REFERENCIA:}

ACTO ADMINISTRATIVO:

RECURRENTE:

APODERADO:

Yo, mayor de edad, estudiante de Consultorio Jurídico, identificado(a) con Cédula de Ciudadanía n.`

de , obrando como de , mayor de edad y vecino de esta ciudad, identificado(a) con la Cédula de Ciudadanía n. ${ }^{\circ}$ por medio del presente escrito formulo recurso de que se sustentará en su oportunidad al acto administrativo que ordena , con base en las siguientes consideraciones:

\section{Capítulo I}

\section{HECHOS}

1.

2.

3.

4.

5.

6. 


\section{Capítulo II}

\section{SUSTENTACIÓN DEL RECURSO}

Analizados los argumentos presentados por el encuentro algunas conclusiones erróneas, las cuales sustento a continuación:

\section{ARGUMENTOS QUE SUSTENTAN EL RECURSO}

\section{Capítulo III}

\section{PETICIÓN}

\section{PRIMERO:}

SEGUNDO:

TERCERO: 


\section{Capítulo IV}

\section{PRUEBAS}

\section{Capítulo V}

\section{FUNDAMENTOS DE DERECHO}

Sustento el presente recurso en lo dispuesto en la Constitución Política de Colombia, artículos 29

Ley , Ley 1437 de 2011, Ley

normas concordantes y antecedentes jurisprudenciales aplicables. de artículo y demás

\section{Capítulo VI}

\section{NOTIFICACIONES}

Recibiré cualquier notificación en la dirección

teléfono y correo

Respetuosamente,

C. C. n. ${ }^{\circ}$ de 


\section{PROCESOS POLICIVOS}

Por Leidy Yobana Marín Abadía

\section{Resumen}

Los procesos policivos se regulan por el Código Nacional de Policía, Ley 1801 de 2016, las ordenanzas departamentales, y en caso de vacío en el procedimiento, se acude al Código General del Proceso. Las acciones posesorias que señala el Código Civil en el artículo 972 y siguientes están estrechamente relacionadas con tres aspectos: poder, función y actividad de Policía.

Palabras clave: lanzamiento por ocupación de hecho, poseedor, posesión, propietario. 


\section{INTRODUCCIÓN}

La finalidad de los procesos policivos es dirimir las controversias que se presentan entre los particulares por ocasión del uso y goce de la propiedad sobre bienes inmuebles. Su fuente sustantiva son las acciones posesorias contempladas en el artículo 972 y siguientes del Código Civil.

La querella civil de Policía es un proceso policivo contemplado en el artículo 79 del Código Nacional de Policía, el cual puede iniciar el poseedor, propietario o incluso el mero tenedor contra un tercero que está perturbando o provocando amenazas o molestias en el ejercicio de la propiedad, posesión o mera tenencia.

El lanzamiento por ocupación de hecho es una acción policiva de carácter sumario y puede iniciarse ya sea para recuperar un bien inmueble urbano o uno agrario. En el primer caso, se inicia ante inspector de Policía, ya sea por el propietario o el poseedor; para los bienes agrarios puede acudirse ante juez civil, teniendo en cuenta la cuantía, o ante inspector de policía. Como la palabra lo indica, procede cuando un tercero invade o entra a un bien inmueble, sin que medie contrato o consentimiento alguno del propietario, poseedor o incluso el mero tenedor.

\section{LANZAMIENTO POR OCUPACIÓN DE HECHO}

Esta acción policiva de carácter sumario puede iniciarse ya sea para recuperar un bien inmueble urbano o uno agrario. En el primer caso se inicia ante inspector de Policía, ya sea por el propietario o el poseedor; para los bienes agrarios, se puede acudir ante juez civil, teniendo en cuenta la cuantía, o ante inspector de Policía. Como la palabra lo indica, procede cuando un tercero invade o entra a un bien inmueble, sin que medie contrato o consentimiento alguno del propietario, poseedor e incluso mero tenedor.

\section{REFERENCIAS}

Ambos, K., Gómez, J. L. y Vogler, R. (2020). (Eds.). La Policía en los Estados de Derecho Latinoamericanos. Ibáñez.

Congreso de la República de Colombia. (2020). Código General del Proceso. Legis.

Congreso de la República de Colombia. (2020). Código Nacional de Policía. Legis.

Coronado Pinto, G. (2020). Derecho de policía aplicado (10. a ed.). Jurídicas Radar.

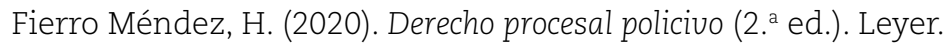




\section{MODELO DE QUERELLA CIVIL DE POLICÍA}

Señor:

Inspector de Policía de

E. S. D.

Referencia: Querella Civil de Policía.

Querellante:

Querellado:

Yo, mayor de edad, domiciliado y residente en , portador(a) de la Cédula de Ciudadanía n. ${ }^{\circ}$

con Tarjeta profesional $n .{ }^{\circ}$ en ejercicio del poder que me ha conferido el/la señor(a) mayor de edad, domiciliado(a) y residente en este mismo municipio, ante Usted presento Querella Civil de Policía contra el/la señor(a) , mayor de edad, domiciliado(a)y residenteen

y como base de la petición que más adelante formularé, expongo los siguientes

\section{HECHOS}

1. Desde el mes de del año mi mandante ha venido ejerciendo de manera pública, pacífica e ininterrumpida una posesión real y material sobre un bien inmueble que a continuación describo.

2. Se trata de un bien inmueble rural consistente en una finca agrícola ubicada en la vereda

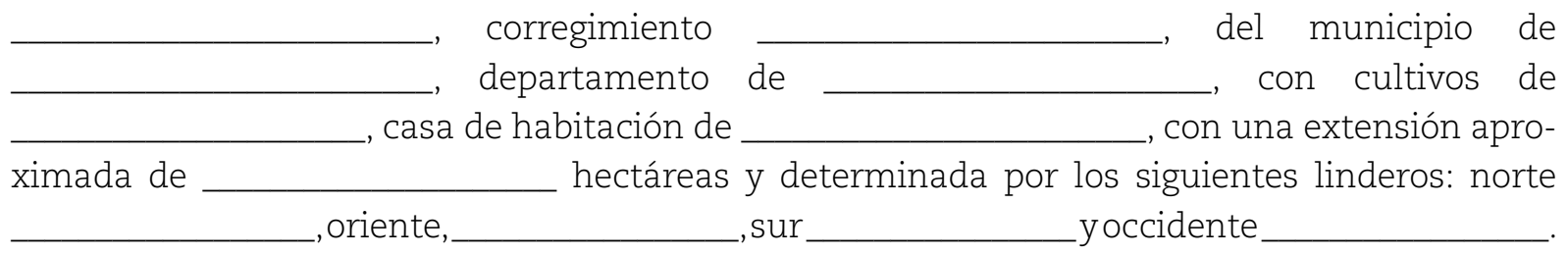

3. Hace menos de... [acá se indica la fecha precisa en que se inició la perturbación, teniendo en cuenta que actualmente son cuatro meses], en la parte suroriental del predio descrito en el hecho segundo de este escrito, en una extensión de aproximadamente, el/ la señor(a) empezó a sembrar distintos árboles, para lo cual corrió los cercos. 
4. Durante el tiempo que mi mandante ha ejercido la posesión, nadie, hasta el día de hoy, ha venido a disputarle el derecho de poseerlo por los linderos generales que ya se indicaron, de donde se deduce que el actuar del demandado es injusto y la autoridad de Policía debe restablecer las cosas a su estado anterior.

\section{PETICIÓN}

Sírvase Señor Inspector, previos los trámites del proceso policivo, decretar el statu quo o amparar la posesión del/la señor(a) (acá querellante) de condiciones civiles ya señaladas y, en consecuencia, ordenar al/la señor(a) , querellado(a), cesar los actos perturba torios, que retornen las cosas a su estado normal, todo bajo la prevención de las medidas que señala el Código Nacional de Policía y Convivencia.

\section{FUNDAMENTOS JURÍDICOS}

Código Nacional de Policía, arts. 76 a 82, 223; Código Civil, arts. 762, 984.

\section{PRUEBAS}

Documentales:

Testimoniales:

\section{COMPETENCIA}

De acuerdo con el factor territorial, la clase de asunto, es Usted competente para conocer del mismo.

\section{ANEXOS}

\section{NOTIFICACIONES}

Atentamente,

C. C. n. ${ }^{\circ}$

Elaborado por Leidy Yobana Marín Abadía. 


\section{MODELO DE QUERELLA CIVIL DE LANZAMIENTO POR OCUPACIÓN DE HECHO}

Señor

INSPECTOR PRIMERO SUPERIOR DE POLICÍA DE

E. S. M.

Yo, mayor de edad, domiciliado(a) y residente en , vecino(a) de esta ciudad, identificado(a) como aparece al pie de mi correspondiente firma, obrando como apoderado del/la señor(a), mayor de edad, domiciliado(a) y residente en , portador de la Cédula de Ciudadanía n. ${ }^{\circ}$ , con-

forme al poder que adjunto, respetuosamente me permito promover ante su Despacho esta Querella Civil de Lanzamiento por Ocupación de Hecho, contra el/la señor(a)

también mayor y de esta vecindad, para que previo al trámite del proceso correspondiente, se ordene el desalojo sobre el inmueble ubicado en la dirección de esta ciudad. Como base de la solicitud, expongo los siguientes:

\section{HECHOS}

PRIMERO: Mi poderdante ha tenido la posesión real y material, de manera pública, pacífica e ininterrumpida desde la fecha en la dirección respecto del inmueble localizado (determinarlos; o si se trata de mero tenedor: "Mi poderdante fue designado secuestre dentro del proceso ejecutivo de , contra

tramitado en el juzgado , de esta ciudad, y desde esa fecha recibió real y materialmente el inmueble mencionado como producto de la diligencia de secuestro ordenada por providencia de fecha , siendo, entonces, tenedor del mismo").

SEGUNDO: En su condición de poseedor material del inmueble descrito anteriormente, mi mandante ha ejercido su señorío a través de continuas y adecuadas actividades económicas tales como cercamiento, construcción y obtención de servicios, etc.

TERCERO: La posesión material la ha ejercido mi representado en nombre propio, con ánimo de señor y dueño, sin que hubiere reconocido dominio alguno ni derecho diferente a otras personas.

CUARTO: Dicha posesión, ejercida sin ningún tipo de violencia y sin el menor signo de clandestinidad sobre el inmueble objeto de esta querella, jamás le fue interrumpida civil ni naturalmente hasta el día , fecha en la cual mi poderdante tuvo conocimiento de que el/la señor(a) lo había ocupado sin que mediara su consentimiento u orden de autoridad competente. (En caso del mero tenedor: "En la mencionada fecha, mi defendido, ejerciendo sus funciones de auxiliar de la justicia, tuvo conocimiento de que el inmueble en mención fue ocupado por el/la citado(a) señor(a), quien se encuentra en el predio sin su consentimiento"). 
QUINTO: Tanto del hecho de la posesión como de la invasión les consta a los señores y , motivo por el cual declaran extrajudicialmente, según se hace constar en los documentos anexos a esta querella y que configuran prueba sumaria al respecto. (En el caso del mero tenedor, solo necesita demostrarse la ocupación no consentida, pues el hecho de la mera tenencia tendrá que demostrarse por la certificación del juzgado que lo designó).

SEXTO: El/la señor(a) en su calidad de poseedor(a) y persona afectada, me ha conferido poder especial para entablar la presente querella (o el citado señor, obrando como secuestre o tenedor del inmueble, me ha conferido poder para iniciar y llevar hasta su terminación el proceso de lanzamiento por ocupación de hecho que hoy se impetra).

Teniendo en cuenta los anteriores hechos, formulo la siguiente

\section{PETICIÓN}

Sírvase, Señor Juez (o Inspector), previos los trámites del proceso de Lanzamiento por Ocupación de Hecho, que trata el Código General del Proceso o normas de Policía que indicaré adelante, dentro del término legal, decrete y disponga la práctica de la diligencia de lanzamiento por ocupación de hecho del inmueble localizado en la dirección de esta ciudad, alinderado de la siguiente forma: (indicar los linderos), procediendo a su restitución mediante el desalojo de las personas que allí se encuentren, al frente de las cuales se halla el/la señor(a). . Así también, que se condene en costas a la parte demandada.

\section{DERECHO}

Me permito invocar como fundamento jurídico lo preceptuado en el artículo 15 de la Ley 57 de 1905, el Decreto 992 de 1930, los artículos 125 a 127 y el Título vi - Capítulo i del Código Nacional de Policía y Convivencia, el artículo 762 del Código Civil o las normas del Código General del Proceso.

Ruego tener como tales las siguientes

\section{PRUEBAS}

Testimonial: Solicito recepcionar el testimonio de las siguientes personas, quienes bajo la gravedad del juramento declaran que sí les

consta que el/la señor(a) tenía una posesión pacífica, pública e

ininterrumpida sobre el bien descrito en el hecho primero de esta querella; sí les consta que el/la señor(a) invadió el predio..., y con el objeto de cumplir con los requisitos exigidos por el Decreto 992 de 1930. (En el caso del mero tenedor, tendrá que acreditarse el acta de diligencia de secuestro del inmueble y la certificación de nombramiento como secuestre del mismo). 


\section{ANEXOS}

Adjunto poder a mi favor, los documentos aducidos como pruebas y copia de la querella para archivo del Despacho. Por la naturaleza del asunto y por el lugar de ubicación del inmueble, es usted competente para conocer y tramitar la presente querella.

\section{NOTIFICACIONES}

Mi poderdante en de esta ciudad.

La demandada en el inmueble objeto de la querella.

El suscrito en la Secretaría del Despacho o en de esta ciudad.

Del señor Alcalde,

Atentamente,

C. C. n. ${ }^{\circ}$

de

T. P. n. ${ }^{\circ}$

Elaborado por Leidy Yobana Marín Abadía. 


\section{PROCESOS EJECUTIVOS}

Por William Díaz Cardona

\section{Resumen}

Cuando se va a ejecutar una obligación, debe tenerse en cuenta si es con base en un título ejecutivo como lo establece el artículo 422 del Código General del Proceso, es decir, determinar muy bien dónde está incorporada la obligación. Igualmente, saber si la prestación es de dar, hacer o no hacer, y de dónde o de qué fuente ha emanado.

Palabras clave: acreedor, deudor, Ejecutivo, prestación, título. 


\section{INTRODUCCIÓN}

La ejecución de las obligaciones es parte del régimen de las obligaciones, por cuanto es la manera como estas se ejecutan, ya sea porque la prestación es de dar, hacer o no hacer. La obligación puede derivarse o nacer, como lo señala el artículo 1494 del Código Civil, de un contrato, la ley, un delito, cuasidelito y otros que han incorporado la jurisprudencia y la doctrina. El proceso ejecutivo es el medio procesal para hacer que la obligación se cumpla, y es un proceso con un trámite diferente a los procesos declarativos, porque en este la solicitud al despacho judicial es que libre mandamiento de pago, no que declare la existencia de una obligación o de un derecho.

Tiene en cierta forma trámite especial, por cuanto las excepciones previas se proponen en el recurso de reposición frente al mandamiento de pago, tal como lo establece el numeral 3 del artículo 442 del Código General del Proceso; es decir, que debe ser dentro de los tres días siguientes a la notificación personal del auto que libra el mandamiento ejecutivo. Igualmente, si va a atacar los requisitos formales del título ejecutivo, debe hacerlo dentro de los tres días siguientes a la notificación, como lo estipula el inciso segundo (2) del artículo 430 del Código General del Proceso.

El proceso ejecutivo está contemplado en el artículo 422 y siguientes del Código General del Proceso. Los requisitos para ejecutar una obligación son:

1. Que sea expresa, o sea, que conste en un contrato, sentencia, resolución, acta de conciliación o algún documento que provenga del deudor ya sea a título ejecutivo o crediticio.

2. Que sea clara, es decir, la obligación no puede ser ambigua en cuanto a su forma de pago o cumplimiento, si está sometida a alguna modalidad.

3. Que sea exigible, que no esté pendiente ningún plazo (suspensivo) o condición (suspensiva). El ejecutivo puede ser hipotecario o prendario, porque en este caso la obligación es con garantía real; en el ejecutivo singular, la obligación es con garantía personal. También existe el ejecutivo complejo, para el cobro de valores o deudas en el caso de los condominios o entidades similares.

Para saber ante quién se dirige la demanda, se tiene en cuenta la cuantía y el factor territorial fuero personal, con la salvedad que establece el numeral 3 del artículo 28 del Código General del Proceso. El proceso ejecutivo de alimentos sigue los lineamientos del Ejecutivo en general para obtener el cumplimiento de la obligación. La demanda se presenta en el domicilio del menor ante el juez de familia, o en su defecto, ante el juez civil municipal; no tiene en cuenta la cuantía.

\section{EL CONTRATO DE TRANSACCIÓN}

El contrato de transacción está contemplado en el artículo 2469 y siguientes del Código Civil, y en el artículo 312 del Código General del Proceso. Su finalidad es precaver un litigio o terminar uno que esté en curso. Igual que en todo contrato, las cláusulas son la base, deben contemplar los pormenores de lo que se busca transar. En el pago de deudas, es importante tener en cuenta si el cumplimiento de la obligación está sometido a plazo extintivo, porque en este caso se coloca la cláusula aceleradora. Dependiendo el caso, también se puede establecer que el contrato hace tránsito a cosa juzgada o que presta mérito ejecutivo. 


\section{REFERENCIAS}

Bonivento Fernández, J. A. y Ospina Fernández, G. (2018). Régimen general de las obligaciones. Temis.

Congreso de la República de Colombia. (2020). Código General del Proceso. Legis.

Congreso de la República de Colombia. (2020). Código Civil. Legis. 


\section{MODELO DE PODER EJECUTIVO SINGULAR}

Señor:

Juez Civil del Circuito de (Reparto).

E. S. D.

Referencia: Poder.

Yo, , mayor de edad, identificado(a) como aparece debajo de mi firma, domiciliado(a) y residente en en calidad de acreedor, respetuosamente manifiesto a Usted que mediante el presente escrito confiero poder especial, amplio y suficiente, al/la abogado(a) , mayor de edad, domiciliado(a) y residente en identificado(a) como aparece debajo de su firma, para que ante Usted inicie y termine proceso ejecutivo singular de mayor cuantía, contra el/la señor(a) (acá identifica al deudor), con el fin de obtener el pago de una obligación de dar, consistente en una suma de dinero en cuantía de m. cte., incorporada en un pagaré (acá indica el título ejecutivo o crediticio); obligación de cargo suyo y actualmente exigible, más los intereses de plazo y moratorios.

Mi apoderado queda facultado para recibir, transigir, conciliar, renunciar, sustituir y reasumir este poder. Igualmente, mediante este escrito, a tenor del artículo 1640 del Código Civil, autorizo al apoderado para recibir la totalidad del pago de la deuda.

Sírvase reconocer personería a mi apoderado dentro de los efectos y términos de este mandato.

Atentamente,

Poderdante,

Acepto,

Elaborado por William Díaz Cardona. 


\section{MODELO DE PODER EJECUTIVO DE ALIMENTOS}

Señor:

Juez Promiscuo de Familia de (Reparto)

E. S. D.

Referencia: Poder.

Yo, mayor de edad, domiciliado(a) y residente en identificado(a) como aparece debajo de mi firma, como representante legal del menor respetuosamente manifiesto a Usted:

Que mediante el presente escrito confiero poder especial, amplio y suficiente al/la abogado(a) , portador(a) de la Tarjeta Profesional n. ${ }^{\circ}$ , expedida por el Consejo Superior de la Judicatura, mayor de edad, domiciliado(a) y residente en la ciudad de identificado(a) como aparece debajo de su firma, para que ante Usted, en mi nombre y representación, inicie y termine PROCESO EJECUTIVO DE ALIMENTOS contra el señor , mayor de edad, identificado(a) con la Cédula de Ciudadanía n. ${ }^{\circ}$ domiciliado y residente en , para obtener el pago de unas cuotas alimentarias desde el año hasta cuyo título ejecutivo es el Acta de Conciliación o sentencia de fecha firmada en obligación de cargo suyo de plazo vencido y actualmente exigible.

Mí apoderado queda facultado para transigir, conciliar, sustituir y reasumir este poder, renunciar, desistir, interponer recursos, solicitar medidas cautelares, y demás facultades que confiere el artículo 77 del Código de General del Proceso.

Sírvase reconocer personería a mi apoderado para actuar dentro de los efectos y términos de este mandato.

Atentamente,

Poderdante,

Acepto Poder 


\section{CONTRATO DE TRANSACCIÓN}

En el municipio de

de de a los entre nosotros

mayor de edad, domiciliado(a) y residente en la ciudad de de la Cédula de Ciudadanía n. ${ }^{\circ}$ , y mayor de edad, con Cédula de Ciudadanía n. , igualmente mayor de edad, domiciliado(a) y residente en acreedoras, y , igualmente mayor de edad, domiciliado(a) y residente en , identificado(a) como aparece debajo de mi firma, por otra parte como deudor, hemos celebrado el presente CONTRATO DE TRANSACCIÓN, con respecto a una obligación de dar consistente en una suma de dinero en cuantía de

(letras y números), el cual se regirá por los artículos 2469, 2470 y siguientes del Código Civil Colombiano y por las siguientes cláusulas:

PRIMERA: El deudor dará una cuota inicial de \$ y el excedente lo seguirá pagando mensualmente en cuotas de $\$$ los días 5 de cada mes a partir del del año hasta cubrir la totalidad de la deuda. Dichas días del mes , portador(a) 


\section{MASC: MÉTODOS ALTERNATIVOS DE SOLUCIÓN DE CONFLICTOS}

Por Diego Thomas Tavera Moncaleano

\section{Resumen}

La conciliación es un mecanismo alternativo de solución de conflictos por medio del cual dos o más personas gestionan por sí mismas, de manera voluntaria y con plenos efectos jurídicos, la solución de sus conflictos con la ayuda de un tercero neutral, calificado y cualificado, llamado conciliador. La experiencia ha demostrado que quienes acuden a la conciliación, salen satisfechos con el acuerdo logrado y sin los traumatismos y resentimientos que se pueden generar con el pronunciamiento que realiza el juez al determinar un ganador y un vencido; de igual forma, no es extraño encontrar personas que entraron con un nivel de enemistad a la audiencia y que, al salir de ella, se encuentren en franca amistad, al igual que familias que retornan al respeto y la confianza que deben existir entre ellos. Todas estas circunstancias, que no son ajenas a las realidades de nuestro entorno, se pueden considerar como ventajas de un procedimiento sencillo, económico, ágil y por demás seguro que contribuye, sin lugar a dudas, a tener una sociedad más pacífica y comprometida con el bienestar común, que se debe reflejar en el quehacer diario de los profesionales del derecho.

Palabras clave: conciliación, conflictos, económico, MASC, solución. 


\section{INTRODUCCIÓN}

Ante las actuales circunstancias que se presentan en la justicia colombiana, donde el cúmulo de procesos judiciales ralentiza el actuar de los servidores públicos, el Estado ha propendido a implementar una figura jurídica que contribuya de manera eficiente a la solución de conflictos sin la necesidad de acudir a la vía judicial. De este modo, imparte normas que legitimen el proceder del ciudadano de a pie como administrador de justicia transitorio, que inste a las personas a dirimir los conflictos de manera armónica, justa y ágil, con la implementación de los llamados métodos alternativos de solución de conflictos (MASC).

Para el futuro abogado, el estudio, la comprensión y la correcta aplicación de los métodos alternativos de solución de conflictos contribuirán a realizar un ejercicio más dinámico del derecho; un ejercicio que se puede desarrollar desde la esfera de lo humano y que posibilitará la solución de los conflictos aplicando un cierto grado de equidad, el cual puede llegar a estar por encima del mismo derecho, pues al procurar la transigencia de las personas, acudiendo a la principal bondad de mecanismos alternativos como la mediación y la conciliación —que corresponden a la resolución de un conflicto en menor tiempo en comparación con una acción judicial-, se estarían resolviendo de raíz enfrentamientos que de otro modo no tendrán solución pronta, por la longevidad de las actuaciones legales, que los destinaría a estar en el rincón de los archivos judiciales.

\section{LOS MÉTODOS}

\section{ALTERNATIVOS DE SOLUCIÓN DE CONFLICTOS (MASC)}

Los MASC son herramientas que ofrecen a las personas la posibilidad de tratar de solucionar sus conflictos por sí mismas o con la ayuda de un tercero sin la necesidad de acudir a la vía judicial; es decir, es la opción que tienen las personas para tratar de resolver conflictos de una manera ágil, expedita, sencilla, amistosa, eficiente y con plenos efectos legales. A diferencia de la justicia tradicional, los MASC presentan características que los diferencian de los procesos judiciales y que les permiten tener, en cierta forma, una eficacia mayor a la justicia tradicional, pues son ágiles, eficientes, económicos y con plenos efectos jurídicos.

A la luz de la legislación colombiana, encontramos que los MASC se clasifican en autocompositivos y heterocompositivos. Los primeros son aquellos donde las personas que se encuentran inmersas en un conflicto tratan de darle una solución a este sin la intervención de un tercero (figura 1).
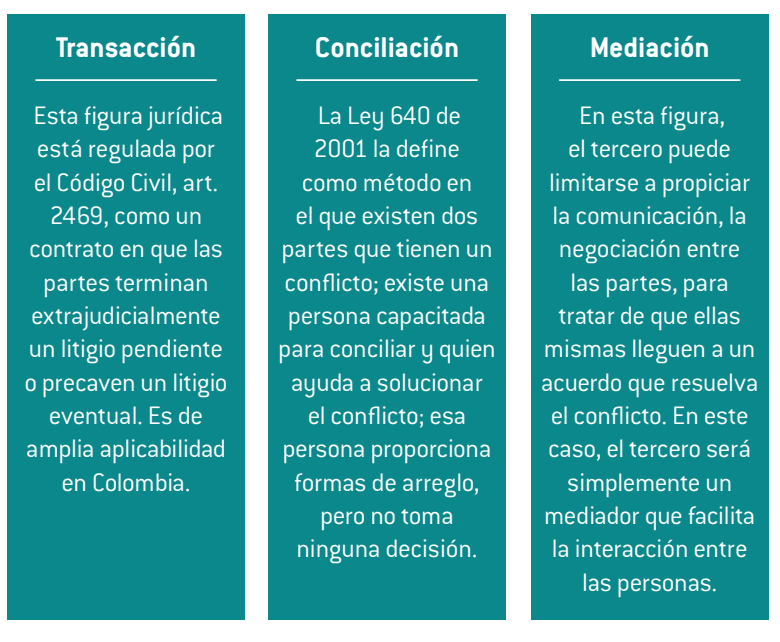

FIGURA 1. Clasificación de los métodos autocompositivos. Elaboración propia.

La importancia de los MASC radica principalmente en lograr que los ciudadanos entiendan que el litigio es el último recurso al cual deben acudir en caso de presentarse un conflicto, que existen otros medios para discutir y solucionar sus problemas en los que los profesionales del derecho o líderes de las comunidades pueden intervenir. Asimismo, de los MAsc heterocompositivos puede decirse que son aquellos donde la solución al conflicto es impartida por un tercero facultado y autorizado para tomar decisiones con fuerza vinculante (figura 2). 

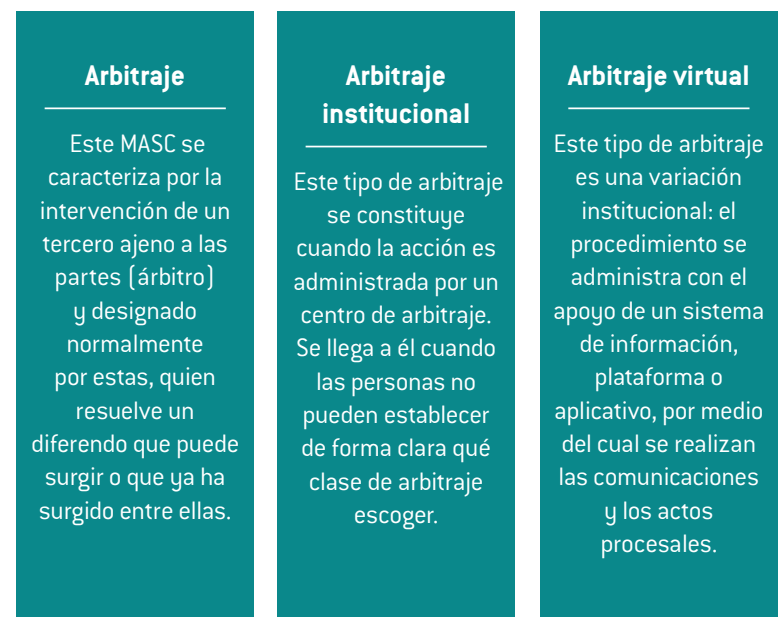

FIGURA 2. Clasificación de los métodos heterocompositivos. Elaboración propia.

En los mecanismos heterocompositivos, resuelve los conflictos un tercero completamente ajeno a las partes, el cual impone una decisión. Esta vía funciona únicamente cuando alguna de las partes así lo decide.

\section{La conciliación}

La conciliación es un mecanismo alternativo de solución de conflictos por medio del cual dos o más personas gestionan por sí mismas, de manera voluntaria y con plenos efectos jurídicos, la solución de sus conflictos con la ayuda de un tercero neutral, calificado y cualificado, llamado conciliador. Este MASC es el método que más usabilidad presenta en nuestro entorno jurídico, pues la sencillez de su procedimiento, la agilidad y la seguridad jurídica lo constituyen en el método alternativo por excelencia para solucionar conflictos.

\section{CLASIFICACIÓN DE LA CONCILIACIÓN}

Existen tres tipos de conciliación: la judicial, la prejudicial y la extrajudicial. Define la Honorable Corte Constitucional, dentro de la Sentencia C-902/08, la conciliación judicial de este modo:

La conciliación judicial es un medio alternativo a la resolución del conflicto, mediante una decisión o fallo. En tal sentido, es una forma especial de poner fin al proceso, siendo el tercero que dirige esta clase de conciliación el juez de la causa, quien además de proponer fórmulas de arreglo, homologa o convalida lo acordado por las partes, otorgándole eficacia de cosa juzgada.

Por su parte, la conciliación prejudicial se entiende como la que se intenta antes de instaurar un proceso judicial, con la finalidad de intentar solucionar el conflicto sin la necesidad de acudir a la vía judicial, agotando en muchos casos el requisito de procedibilidad. Por último, la conciliación extrajudicial es aquella donde, existiendo un proceso judicial en curso, se intenta solucionar el conflicto por fuera de los estrados judiciales, para después ser introducida la decisión en el proceso y así poner fin a este.

\section{ELEMENTOS DE LA CONCILIACIÓN}
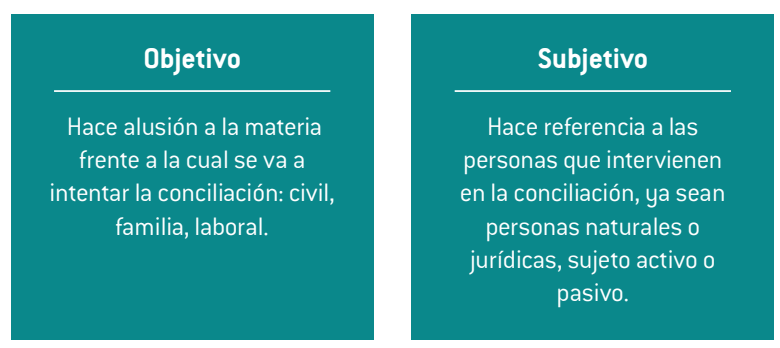

FIGURA 3. Elementos objetivos y subjetivos de la conciliación. Elaboración propia.

\section{LAS VENTAJAS DE LA CONCILIACIÓN}

En primera medida, la conciliación tiene una libertad de acceso al ser una figura que se fundamenta en la autonomía de la voluntad de las partes; por ello, cualquier ciudadano puede acudir a la conciliación como una alternativa para solucionar sus conflictos. Las personas pueden acudir libremente a un centro de conciliación, ante un funcionario público habilitado por la ley para conciliar o ante un notario para solicitar una conciliación. Así, la mayoría de personas que acuden a la conciliación obtienen satisfacción con el acuerdo logrado, toda vez que este es fruto de su propia voluntad. 
Asimismo, la conciliación es un procedimiento mediante el cual las personas solucionan sus conflictos de una forma más rápida en comparación con la duración de los procesos judiciales en Colombia. La conciliación tiene la duración que las personas establezcan de común acuerdo con el conciliador; por lo general, las conciliaciones se desarrollan en una sola audiencia, lo que se traduce en una justicia celera. Por otro lado, y teniendo en cuenta que la conciliación es un procedimiento rápido, las partes se ahorran los costos implicados en un largo proceso judicial, además de que pueden o no utilizar los servicios de un abogado.

\section{EFECTOS DE LA CONCILIACIÓN}

A la luz de la normatividad colombiana, la conciliación tiene dos efectos jurídicos: hace tránsito a cosa juzgada y presta mérito ejecutivo. Se entiende el primer efecto como la imposibilidad de volver a debatir por los mismos hechos o las mismas pretensiones en conflicto solucionado, y como la posibilidad de exigir el incumplimiento de lo acordado ante la autoridad competente.

\section{EL CONCILIADOR}

El conciliador se entiende como un tercero neutral e imparcial que aporta su guía y facilita la comunicación entre las personas para que estas lleguen a un acuerdo. Por disposición legal, el conciliador debe ser abogado, con excepción de los estudiantes de las facultades de Derecho que estén cursando la materia Consultorio Jurídico y que se encuentren inscritos en Ministerio de Justicia y Derecho como estudiantes conciliadores.

Asimismo, la normatividad reviste la facultad de conciliar a los estudiantes de último año de Psicología y Trabajo Social que hayan sido capacitados para tal efecto, al igual que los jueces laborales, civiles e inspectores del trabajo. Es importante recalcar que a quienes actúen como conciliadores les acuden las mismas causales de recusación e impedimentos previstos para los jueces en la legislación civil colombiana.

\section{Obligaciones de los conciliadores}

De conformidad con la Ley 640 de 2001, el conciliador se entiende como el director de la audiencia y tiene las siguientes obligaciones:

- Citar a las personas de conformidad con la ley.

- Hacer concurrir a quien en su criterio deba asistir a la audiencia.

- Ilustrar a los comparecientes sobre el objeto, el alcance y los límites de la conciliación.

- Motivar a las personas para llegar a un acuerdo.

- Presentar fórmulas de arreglo.

- Redactar los diferentes documentos que nazcan de las decisiones de las personas en la audiencia.

- Realizar el registro de los documentos en la plataforma que para tal efecto determine la ley (SICAAC).

\section{Procedimiento conciliatorio}

Este inicia, en el caso del Centro de Conciliación de la Universidad Cooperativa de Colombia, con el diligenciamiento de la solicitud de conciliación, la cual debe ser remitida al director del Centro con la finalidad de verificar que cumpla con los requisitos mínimos.

Después de ser recibida y revisada por el director del Centro de Conciliación, este realiza el reparto y selecciona al conciliador designado para asistir la audiencia, quien debe emitir concepto mediante el cual determina si el 
asunto es conciliable o no. En caso de que el asunto sea de aquellos que no se pueden conciliar, el conciliador debe emitir una constancia de asunto no conciliable, la cual debe ser notificada al convocante y registrada en el Sistema de Información de la Conciliación, el Arbitraje y la Amigable Composición (SICAAAC).

Cuando el asunto sea conciliable, el conciliador debe diligenciar los oficios de notificación, los cuales deben ser enviados por correo certificado al convocado y notificados personalmente en la oficina del director del centro al convocante, quien debe firmar en ese momento tanto la notificación como la radicación del procedimiento conciliatorio en señal de aceptación de la hora y la fecha de la audiencia.

Es importante recordar que, conjuntamente con la citación a la audiencia de conciliación, al convocado se le debe remitir copia de la solicitud de conciliación, la cual debe estar acompañada de copia simple de los anexos presentados.

\section{La audiencia de conciliación}

En el desarrollo de la audiencia de conciliación, se conocen cinco etapas, una de ellas previa al desarrollo de la audiencia y cuatro posteriores a esta.

\section{ETAPA PREVIA}

Es aquella en la que el conciliador realiza la preparación de la audiencia, con la finalidad de verificar que todo se encuentra en perfectas condiciones para su desarrollo. El conciliador debe asistir al centro de conciliación con no menos de media hora de antelación al inicio de la audiencia, con la finalidad de verificar que la sala cumpla con lo necesario para el desarrollo de la audiencia, que el lugar se encuentra en perfectas condiciones de aseo, que el mobiliario es suficiente para el número de personas que asistirán a la audiencia, y que los sistemas informáticos como internet, computadores e impresoras funcionan en prefectas condiciones.

Del mismo modo, el conciliador debe solicitar en la secretaría del centro el expediente del caso, el cual ya debe haber sido estudiado en su totalidad por el conciliador y con base en el cual este debe haber planeado su hoja de ruta de la audiencia, en la cual habrá consignado las fórmulas de arreglo que presentará a las personas, en caso de que estas no estén logrando un acuerdo.

\section{ETAPA DE INSTALACIÓN DE LA AUDIENCIA}

Esta etapa inicia con la verificación de la asistencia de las personas a la audiencia, quienes deben ingresar a la sala y ubicarse en el lugar y la forma que el conciliador determine (figura 4).

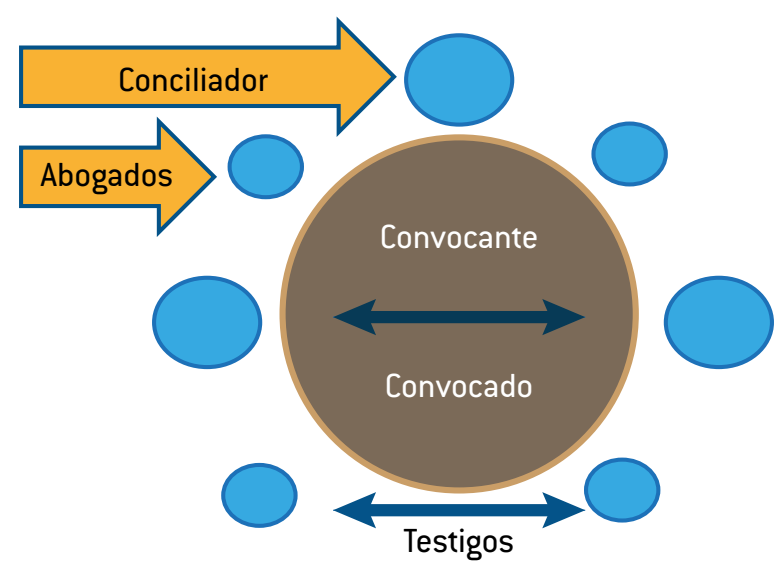

FIGURA 4. Instalación de la audiencia. Elaboración propia.

Ya ubicadas las personas en la sala de conciliación, el conciliador debe solicitar a los asistentes que exhiban sus documentos de identidad con la finalidad de constatar sus identidades, las cuales deben se confrontadas con las que reposan en el expediente. Verificada la identidad de los asistentes, el conciliador tiene la obligación de ilustrar a las personas acerca de la conciliación, explicando detenidamente qué es el proceso, cuáles son sus ventajas, sus efectos y los posibles resultados que puedan nacer del ejercicio conciliatorio. 
Para terminar la etapa de instalación de la audiencia, el conciliador debe indicar a los asistentes las reglas que se seguirán en el desarrollo de la audiencia, tales como dirigirse a todos los asistentes con el debido respeto, no utilizar palabras soeces, peyorativas o discriminatorias, hablar en un tono de voz adecuado al recinto y dentro de las oportunidades que el conciliador determine, no golpear o mover la mesa de manera violenta, no exponer en la mesa temas que no hayan sido presentados en la solicitud, así como todas las demás recomendaciones que el conciliador y el centro de conciliación determinen para el correcto desarrollo del mecanismo.

\section{DETERMINACIÓN DEL CONFLICTO}

Habiéndose instalado la audiencia, el conciliador dará la oportunidad al convocante para que este indique los hechos que lo llevaron a solicitar la audiencia; posteriormente concederá el uso de la palabra al convocado con la finalidad de determinar que los hechos y las pretensiones indicados en esta etapa de la audiencia se encuentran en armonía con los presentados en la solicitud. Requerirá a las personas que, en caso de no coincidir, se limiten a los hechos y las pretensiones plasmados en el documento.

\section{ETAPA CONCILIATORIA}

Es la etapa de discusión y arreglo directo de los conflictos; es además la etapa en la que las personas presentan sus planteamientos del problema y las propuestas de arreglo. En el caso de que la etapa conciliatoria no esté dando el resultado esperado (llegar a un acuerdo), el conciliador debe presentar sus fórmulas de arreglo, con la finalidad de llegar a un feliz término.

\section{CIERRE DE LA AUDIENCIA}

Finalizada la etapa conciliatoria, y dependiendo de su resultado, el conciliador debe redactar el acta de conciliación o las constancias a que haya lugar, las cuales deben ser leídas en voz alta por el conciliador antes de la firma de quienes intervinieron en la audiencia. Los documentos suscritos se entregan en original pasados tres días hábiles, teniendo en cuenta que deben ser registrados en el SICAAAC. Llegado el término de cumplimiento de los acuerdos, el centro de conciliación debe efectuar el control posterior al acuerdo, el cual consiste en verificar su cumplimiento, para proceder a archivar.

\section{REFERENCIAS}

Barreto, A (2012). Curso de conciliación.Ediciones Doctrina y Ley.

Junco, J (2015). La conciliación. Aspectos sustanciales. Ediciones Jurídicas Radar.

Talero, G. (2003). Nueva guía del derecho. Intermedio. 


\section{LA ACCIÓN DE TUTELA}

Por Valerie M. Vallejo Vilaró

\section{Resumen}

La acción de tutela es una garantía constitucional que tienen todas las personas para activar el aparato judicial en busca de obtener una protección inmediata de sus derechos fundamentales y así evitar un perjuicio o daño irremediable. En esta oportunidad se presenta un capítulo práctico y concreto sobre la acción de tutela, así como un modelo de presentación. La finalidad de esta guía es ser una herramienta de ayuda para los estudiantes adscritos al Consultorio Jurídico de la Universidad Cooperativa de Colombia, tanto para las asesorías brindadas a los usuarios como para ejercer la protección de los derechos ante los entes judiciales y administrativos correspondientes.

Palabras clave: acción de tutela, derecho constitucional, derechos fundamentales, desacato, garantía constitucional. 


\section{INTRODUCCIÓN}

La acción de tutela es un mecanismo constitucional que fue consagrado en nuestra Carta Magna como vehículo idóneo para proteger los derechos fundamentales que se vean afectados o vulnerados de forma directa o indirecta. En los últimos tiempos, la acción de tutela ha sido el mecanismo más usado por las personas para impetrar la protección de derechos como el debido proceso, cuando se ha realizado la presentación de un derecho de petición ante autoridades, entidades públicas o privadas y estas no han dado respuesta dentro de los términos legales. Por otra parte, también ha sido usada como mecanismo eficiente para la protección de los derechos de la salud, como son cirugías, exámenes médicos, entregas de medicamentos, entre otros; así como en la protección al derecho de la igualdad, el derecho al trabajo, etc. Como se evidencia, la acción de tutela es una figura judicial de alto uso constante por las personas, dada su efectividad para amparar sus derechos.

\section{CONCEPTOS Y MINUTA DE ACCIÓN DE TUTELA}

\section{Conceptos: acción de tutela e incidente de desacato}

¿Cuándo procede la acción de tutela? La acción de tutela, conforme al artículo 86 de la Constitución Política de Colombia ${ }^{1}$, procede cuando puede existir un perjuicio, cuando se ha ocasionado un daño y se sigue causando en el tiempo por la acción u omisión de entidades públicas, privadas o persona naturales, y cuando no se cuenta con ningún otro medio o mecanismo de defensa judicial idóneo para salvaguardar los derechos fundamentales, a excepción de cuando lo que

1 Reglamentada por el Decreto 2591 de 1991. se pretende es evitar de forma transitoria un perjuicio irremediable².

La acción de tutela como garantía constitucional busca la protección de los derechos fundamentales que se encuentran respaldados por nuestra Carta Magna ${ }^{3}$, como son el derecho a la vida (art. 11.), el derecho a la integridad personal (art. 12), el derecho de petición (art. 23), el derecho a la igualdad (art. 13), el derecho al debido proceso (art. 29), el derecho a la intimidad personal (art. 15), el derecho a la libertad de culto (art. 19), el derecho al trabajo (art. 25), el derecho a la salud (Ley Estatutaria 1751 de 2015), el derecho a la seguridad social (art. 49), así como todos los derechos fundamentales de los niños y las personas de la tercera edad.

Ahora bien, no son los únicos derechos que pueden protegerse a través de este mecanismo; también funge como vehículo de protección frente a aquellos derechos que, si bien no se encuentran tipificados en nuestra Constitución Política como derechos fundamentales, por conexidad con estos, se pueden proteger para evitar perjuicios indirectos a aquellos que sílo son.

¿Cuándo no procede la acción de tutela? La acción de tutela no procede cuando el daño ya se encuentra consumado, cuando se cuenta con otro recurso o medio de defensa judicial que permitan proteger los derechos o dar solución a estos, cuando se pueda ejercer la acción del Habeas Corpus, o cuando verse sobre vulneración de derechos colectivos.

\section{Características de la acción de tutela}

La acción de tutela es una de los mecanismos constitucionales que gozan de mayor agilidad y

\footnotetext{
2 Se entiende por irremediable el perjuicio que solo pueda ser reparado en su integridad mediante una indemnización, según se establece en la Sentencia C-531/93 de la Corte Constitucional. 3 Constitución Política de Colombia, Capítulo I del Título II.
} 
ausencia de formalismos ${ }^{4}$. Es un medio en que las personas pueden impetrar la protección de sus intereses incluso sin la intervención de un abogado; tampoco se hace necesaria la fundamentación jurídica correspondiente, siempre y cuando en su cuerpo se logre evidenciar de forma clara y precisa el derecho vulnerado.

En otras palabras, puede decirse que la acción de tutela se encuentra investida de características como la subsidiariedad ${ }^{5}$, debido a que no debe existir otro medio efectivo para garantizar los derechos; inmediatez ${ }^{6}$, toda vez que el fallo se debe acatar y cumplir sin dilaciones; informal 7 , por la ausencia de sus requisitos para presentación ante el aparato judicial; preferente $^{8}$, ya que se deben preferir las acciones de tutela por encima de cualquier otra actuación; y sumaria ${ }^{9}$, porque es sencilla en sus formas y procedimientos.

La acción de tutela, conforme a lo establece el artículo 10 del Decreto 2591 de 1991, puede ser interpuesta a nombre propio, por un agente oficioso ${ }^{10}$, por un representante de la parte, por un representante legal, por un apoderado o abogado, por el defensor del pueblo y/o la Personería Municipal.

Es menester dejar claro que el artículo 7 del Decreto 2591 de 1991 da la posibilidad de solicitar una medida provisional al juez, la cual consiste en hacer o no determinadas actuaciones con la finalidad de evitar la comisión o producción de daños irremediables. Esta protección también puede ser ordenada oficiosamente por el juez en caso de considerarlo necesario y pertinente.

4 En comparación con los requisitos procesales que se deben ceñir a otro tipo de actuaciones procesales previstas en la Ley.

5 Art. 6 n. ${ }^{0} 1$ del Decreto 2591 de 1991.

6 Art. 18 del Decreto 2591 de 1991

7 Art. 1 del Decreto 2591 de 1991.

8 Art. 1 del Decreto 2591 de 1991.

9 Art. 1 del Decreto 2591 de 1991.

10 Se entiende por agente oficioso un tercero que actúa en beneficio del titular, cuando este no se encuentre en condiciones de realizar o promover su propia defensa.
¿Qué jueces son los competentes para resolver la acción de tutela? En principio, todos los jueces son competentes para resolver este tipo de solicitudes. Sin embargo, el Decreto 1382 de 2000, artículo $1^{11}$, regula unos ítems sobre competencia: se impone en primera medida que el juez competente para conocer de la acción de tutela está en razón de la territorialidad, es decir, en el lugar de ocurrencia de los hechos. Lo anterior, conforme a las siguientes reglas:

1. Las acciones de tutela que se interpongan contra cualquier autoridad pública del orden nacional, salvo lo dispuesto en el siguiente inciso, serán repartidas para su conocimiento, en primera instancia, a los tribunales superiores de distrito judicial, administrativos y consejos seccionales de la judicatura.

A los jueces del circuito o con categorías de tales, le[s] serán repartidas para su conocimiento, en primera instancia, las acciones de tutela que se interpongan contra cualquier organismo o entidad del sector descentralizado por servicios del orden nacional o autoridad pública del orden departamental.

A los jueces municipales les serán repartidas para su conocimiento en primera instancia las acciones de tutela que se interpongan contra cualquier autoridad pública del orden distrital o municipal y contra particulares.

Las acciones de tutela dirigidas contra la aplicación de un acto administrativo general dictado por una autoridad nacional serán repartidas para su conocimiento al Tribunal Contencioso Administrativo de Cundinamarca, siempre que se ejerzan

11 Decreto 2591 de 1991, artículo 37. 
como mecanismo transitorio para evitar un perjuicio irremediable.

Cuando la acción de tutela se promueva contra más de una autoridad y estas sean de diferente nivel, el reparto se hará al juez de mayor jerarquía, de conformidad con las reglas establecidas en el presente numeral.

2. Cuando la acción de tutela se promueva contra un funcionario o corporación judicial, le será repartida al respectivo superior funcional del accionado. Si se dirige contra la Fiscalía General de la Nación, se repartirá al superior funcional del juez al que esté adscrito el fiscal.

Lo accionado contra la Corte Suprema de Justicia, el Consejo de Estado o el Consejo Superior de la Judicatura, Sala Jurisdiccional Disciplinaria, será repartido a la misma corporación y se resolverá por la Sala de Decisión, sección o subsección que corresponda de conformidad con el reglamento al que se refiere el artículo $4^{\circ}$ del presente decreto.

Cuando se trate de autoridades administrativas en ejercicio de funciones jurisdiccionales, conforme al artículo 116 de la Constitución Política, se aplicará lo dispuesto en el numeral $1^{\circ}$ del presente artículo.

PAR. - Si conforme a los hechos descritos en la solicitud de tutela el juez no es el competente, este deberá enviarla al juez que lo sea a más tardar al día siguiente de su recibo, previa comunicación a los interesados. En este caso, el término para resolver la tutela se contará a partir del momento en que sea recibida por el juez competente. (Decreto 1382 de 2000, artículo 1)
En síntesis, todos los jueces son competentes para conocer de las acciones de tutela, aunque deben tenerse en cuenta los factores de competencia consagrados en el Decreto 1382 de 2000. No obstante, conviene recordar que es un mecanismo preferente y, por lo tanto, los jueces no pueden dilatar los fallos, y en caso tal de sentirse impedidos, deberán realizar la remisión al juez de competencia a que haya lugar.

\section{Términos de la acción de tutela}

El Decreto 2591 de 1991 dispone de forma taxativa que el juez que conoce del proceso cuenta con un término de diez (10) días para proferir fallo respecto de la solicitud impetrada, decisión que en ningún evento deberá superar el término de cuarenta y ocho (48) horas ${ }^{12}$ para su cumplimiento. Posterior a la emisión de sentencia en primera instancia, la parte vencida cuenta con el término de tres (3) días para impugnar la decisión argumentando las razones de hecho en que se fundamenta. Frente a esta solicitud, el juez de segunda instancia cuenta con un término de veinte (20) días para resolver la impugnación presentada.

\section{Consecuencias del incumplimiento de un fallo de tutela}

¿Qué sucede si una de las partes no cumple o no acata lo dispuesto en el fallo de tutela proferido por un juez? La consecuencia que se le impone a la parte por el incumplimiento de lo dispuesto en un fallo de tutela puede ser la medida privativa de la libertad por el término de seis (6) meses y una multa de hasta veinte

12 Decreto 2591 de 1991, artículo 29. 
(20) SmLMv. Para que un juez pueda imponer algún tipo de sanción por el incumplimiento de un fallo, es necesario que se ponga en conocimiento del juez de primera instancia —es decir, quien profirió dicho fallo- sobre la desobediencia o el incumplimiento de este. Esta acción se realiza a través de un incidente de desacato, el cual debe ser remitido en grado de consulta al Superior Jerárquico.

\section{Requisitos de la acción de tutela}

¿Qué debe contener una acción de tutela?

- Nombre completo e identificación del solicitante. Si actúa a través de apoderado o agente oficioso, se debe suministrar su identificación completa.

- Identificación del accionado (autoridad pública o particular).

- Relación cronológica detallada de los hechos objeto de protección (que vulneren el o los derechos fundamentales).

- Exposición de las razones de hecho y de derecho que se considera afectan o vulneran sus derechos.

- Manifestar bajo la gravedad de juramento que no se ha accionado el aparato judicial sobre los mismos hechos.

- Dirección de notificación.

- Anexos: poder, en caso de actuar a través de apoderado; fotocopia de la cedula de ciudadanía; cualquier otro documento que permita vislumbrar la vulneración o posible vulneración del derecho, en caso de que se cuente con ello.

\section{DERECHO DE PETICIÓN}

El derecho de petición es uno de los derechos fundamentales consagrados por nuestra Constitución Política de Colombia en su artículo 23, que reza:

Toda persona tiene derecho a presentar peticiones respetuosas a las autoridades por motivos de interés general o particular y a obtener pronta resolución. El legislador podrá reglamentar su ejercicio ante organizaciones privadas para garantizar los derechos fundamentales.

El derecho de petición no solo se encuentra respaldado por nuestra Norma de Normas, sino que también goza de regulación en la Ley 1755 de 2015, donde se disponen otras regulaciones al respecto. Se desprende de las citadas normas que toda persona, sea natura o jurídica, puede presentar peticiones respetuosas a las autoridades, ya sea porque se tenga un interés general o un interés particular, con la finalidad de obtener una respuesta completa $\mathrm{y}$ de fondo.

¿Qué se puede pedir a través de un derecho petición? El derecho de petición es el mecanismo a través del cual se puede solicitar el reconocimiento de un derecho; la intervención de una entidad o funcionario; la resolución de una situación jurídica; la prestación de un servicio; requerir información; consultar, examinar y requerir copias de documentos; formular consultas, quejas, denuncias y reclamos, e interponer recursos (Ley 1755 de 2015, artículo 13).

Es preciso resaltar que estas actuaciones son gratuitas y gozan de informalidad en su presentación, ya que no requieren de mayores formalismos para elevar dicha solicitud; tampoco se requiere un abogado para actuar. 


\section{Términos del derecho de petición}

TABLA 2

Términos del derecho de petición

\begin{tabular}{|c|c|c|}
\hline Petición & ¿Qué es? & ¿Cuándo debe resolverse? \\
\hline $\begin{array}{l}\text { Derecho de } \\
\text { petición en } \\
\text { interés general }\end{array}$ & $\begin{array}{l}\text { Solicitud que una persona o una comunidad presenta ante las autoridades para que } \\
\text { se preste un servicio o se cumpla una función propia de la entidad, con el fin de } \\
\text { resolver necesidades de tipo comunitario. }\end{array}$ & $\begin{array}{l}\text { Dentro de los } 15 \text { días hábiles } \\
\text { siguientes a su recepción. }\end{array}$ \\
\hline $\begin{array}{l}\text { Derecho de } \\
\text { petición en } \\
\text { interés particular }\end{array}$ & $\begin{array}{l}\text { Solicitud que una persona hace ante una autoridad, con el fin de que se le resuelva } \\
\text { determinado interrogante, inquietud o situación jurídica que solo le interesa a él o a } \\
\text { su entorno. }\end{array}$ & $\begin{array}{l}\text { Dentro de los } 15 \text { días hábiles } \\
\text { siguientes a su recepción. }\end{array}$ \\
\hline Queja & $\begin{array}{l}\text { Manifestación de protesta, censura, descontento o inconformidad que formula } \\
\text { una persona en relación con una conducta que considera irregular de uno o varios } \\
\text { servidores públicos en desarrollo de sus funciones. }\end{array}$ & $\begin{array}{l}\text { Dentro de los } 15 \text { días hábiles } \\
\text { siguientes a su recepción. }\end{array}$ \\
\hline Reclamo & $\begin{array}{l}\text { Manifestación de inconformidad, referente a la prestación indebida de un servicio o } \\
\text { a la falta de atención de una solicitud. }\end{array}$ & $\begin{array}{l}\text { Dentro de los } 15 \text { días hábiles } \\
\text { siguientes a su recepción. }\end{array}$ \\
\hline Sugerencia & $\begin{array}{l}\text { Manifestación de una idea, opinión, aporte o propuesta para mejorar el servicio o la } \\
\text { gestión de la entidad. }\end{array}$ & $\begin{array}{l}\text { Dentro de los } 15 \text { días hábiles } \\
\text { siguientes a su recepción. }\end{array}$ \\
\hline $\begin{array}{l}\text { Denuncia por } \\
\text { posibles actos de } \\
\text { corrupción }\end{array}$ & $\begin{array}{l}\text { Manifestación que puede realizar cualquier ciudadano para enterar a las autoridades } \\
\text { de la existencia de hechos contrarios a la ley, incluidos los relacionados con } \\
\text { contratación pública, con el fin de activar mecanismos de investigación y sanción, } \\
\text { dar a conocer conductas constitutivas en faltas disciplinarias por incumplimiento } \\
\text { de deberes, extralimitación de funciones, prohibiciones y violación del régimen de } \\
\text { inhabilidades, incompatibilidades, impedimentos y conflicto de intereses de un } \\
\text { servidor público. }\end{array}$ & $\begin{array}{l}\text { Dentro de los } 15 \text { días hábiles } \\
\text { siguientes a su recepción. }\end{array}$ \\
\hline Felicitación & $\begin{array}{l}\text { Manifestación de un ciudadano en la que expresa la satisfacción con motivo de } \\
\text { algún suceso favorable para él, con relación a la prestación del servicio por parte de } \\
\text { una entidad pública. }\end{array}$ & $\begin{array}{l}\text { Dentro de los } 15 \text { días hábiles } \\
\text { siguientes a su recepción. }\end{array}$ \\
\hline $\begin{array}{l}\text { Solicitud de } \\
\text { acceso a la } \\
\text { información }\end{array}$ & $\begin{array}{l}\text { Facultad que tiene la ciudadanía de solicitar y obtener acceso a la información sobre } \\
\text { las actualizaciones derivadas del cumplimiento de las funciones atribuidas, solicitud } \\
\text { de registros, informes, datos o documentos producidos o en posesión, control o } \\
\text { custodia de una entidad. }\end{array}$ & $\begin{array}{l}\text { Dentro de los } 10 \text { días hábiles } \\
\text { siguientes a su recepción. }\end{array}$ \\
\hline $\begin{array}{l}\text { Solicitud de } \\
\text { copias }\end{array}$ & $\begin{array}{l}\text { Reproducción y entrega de documentos que no tengan el carácter de reservado } \\
\text { en el interior de una entidad, como expedientes misionales, jurisdiccionales o } \\
\text { administrativos. Cuando la información solicitada repose en un formato electrónico, } \\
\text { y el solicitante así lo manifieste, se podrá enviar por este medio y no se le cobrará } \\
\text { costo de reproducción excepto si lo solicita en CD, DVD u otro formato. Cuando el } \\
\text { volumen de las copias es significativo, se podrán expedir, a costas del solicitante, } \\
\text { según los costos de reproducción de cada entidad. }\end{array}$ & $\begin{array}{l}\text { Dentro de los } 10 \text { días hábiles } \\
\text { siguientes a su recepción. }\end{array}$ \\
\hline Consulta & $\begin{array}{l}\text { Solicitud de orientación a las autoridades en relación con las materias a su cargo, } \\
\text { cuya respuesta no tiene efectos jurídicos directos sobre el asunto que trata, por lo } \\
\text { tanto, no es de obligatorio cumplimiento. }\end{array}$ & $\begin{array}{l}\text { Dentro de los } 30 \text { días hábiles } \\
\text { siguientes a su recepción. }\end{array}$ \\
\hline
\end{tabular}


- Exposición de las razones de hecho y de derecho en que se fundamenta la decisión.

- Dirección de notificaciones.

- Firma del solicitante.

- Anexos: poder, en caso de actuar a través de apoderado; fotocopia de la cedula de ciudadanía; cualquier otro documento que permita vislumbrar la vulneración o posible vulneración del derecho, en caso de que se cuente con ello.

\section{REFERENCIAS}

Corte Constitucional de Colombia, Sala Plena. (1993). Demanda n. ${ }^{\circ}$ D-258, Sentencia n. ${ }^{\circ}$ C-531/93, M. P.: Eduardo Cifuentes Muñoz, 11 de noviembre de 1993.

Congreso de la República de Colombia (1991). Constitución Política de Colombia. Legis.

Presidencia de la República de Colombia. (1991). Decreto 2591 de 1991, por el cual se reglamenta la acción de tutela consagrada en el artículo 86 de la Constitución Política. https://bit.ly/3AACOsu

Presidencia de la República de Colombia. (2000). Decreto 1382 de 2000, por el cual establecen reglas para el reparto de la acción de tutela. https://bit.ly/3ArwwjX

Congreso de la República de Colombia. (2015). Ley Estatutaria 1751 de 2015, por medio de la cual se regula el derecho fundamental a la salud y se dictan otras disposiciones. https://bit.ly/2X5u8Sg

Congreso de la República de Colombia. (2015). Ley 1755 de 2015, por medio de la cual se regula el Derecho Fundamental de Petición y se sustituye un título del Código de Procedimiento Administrativo y de lo Contencioso Administrativo. https://bit.ly/3DqEE5Y 


\section{MINUTA DE ACCIÓN DE TUTELA}

SEÑOR

JUEZ CIVIL MUNICIPAL (REPARTO)

E. S. D.

Ref.: Acción de tutela para proteger el derecho fundamental de petición.

Accionante:

Accionado:

Yo, , identificado(a) como aparece al pie de mi firma, actuando en nombre propio, invocando el artículo 86 de la Constitución Política, acudo ante su Despacho para instaurar ACCIÓN DE TUTELA contra , con el objeto de que se protejan los derechos constitucionales fundamentales que a continuación enuncio y los cuales se fundamentan en los siguientes

\section{HECHOS}

(Presente una relación detallada y clara de los hechos donde se genera la violación del derecho fundamental.)

1.

2.

3.

\section{DERECHOS VULNERADOS}

Derecho fundamental de de la Constitución Política de Colombia de 1991.

\section{FUNDAMENTOS JURÍDICOS}

(Exposición argumentativa jurídica donde se evidencie la vulneración de los derechos) 


\section{PRUEBAS}

Con el fin de establecer la vulneración de los derechos, solicito, Señor Juez, se sirva tener en cuenta las siguientes pruebas:

\section{PRETENSIONES}

Con fundamento en los hechos relacionados, solicito al Señor Juez disponer y ordenar:

PRIMERO: Tutelar el derecho fundamental

SEGUNDO: Ordenar (ejecución o no ejecución).

\section{FUNDAMENTOS DE DERECHO}

Fundamento esta acción en el artículo los artículos , que se encuentran contemplados los derechos vulnerados.

\section{ANEXOS}

1.

2.

\section{JURAMENTO ART. 37 DE DECRETO 2591 DE 1991}

Manifiesto bajo la gravedad del juramento que no se ha presentado ninguna otra acción de tutela por los mismos hechos y derechos.

\section{NOTIFICACIONES}

(Dirección para recibir comunicaciones)

Accionante:

Accionado:

Atentamente,

C.C. de 


\section{MINUTA DE INCIDENTE DE DESACATO}

Señor

Juez (que concedió la tutela en primera instancia).

E. S. D.

\section{Asunto: Incidente de desacato de acción de tutela n. ${ }^{\circ}$}

Yo, identificado(a) como aparece al pie de mi firma, me permito presentar INCIDENTE DE DESACATO de la sentencia con fecha proferida por este despacho, contra la entidad representada legalmente por , o quien haga sus veces, con fundamento en los siguientes

\section{HECHOS}

1. El día presenté acción de tutela contra (nombre de la entidad o persona respectiva).

2. El día , su Honorable Juez resolvió la acción constitucional emitiendo como fallo: "(transcribir lo profirió por el despacho)":

3. Hasta la fecha de la presentación de este incidente, el accionado no ha cumplido con la orden del despacho y la situación que motivó la tutela sigue vigente.

\section{PRETENSIONES}

Con base en lo expuesto anteriormente, solicito al Señor Juez disponer y ordenar:

1. (nombre de la entidad o persona respectiva) el cumplimiento del fallo.

2. IMPOSICIÓN de multa y la orden de arresto que están prescritos en la norma.

\section{FUNDAMENTOS DE DERECHO}

Decreto 2591 de 1991, artículo 52, y Decreto 306 de 1992, artículo 9. 


\section{NOTIFICACIONES}

Accionante:

Accionado:

Cordialmente,

Firma del solicitante:

Identificación: 


\section{MINUTA DE DERECHO DE PETICIÓN}

Señores:

Nombre de la Entidad o nombre del funcionario

Cargo del funcionario

E. S. M.

Asunto: Derecho de Petición

Peticionario:

Identificación:

En ejercicio del Derecho de Petición consagrado en el artículo 23 de la Constitución Política de Colombia, respetuosamente me dirijo a su despacho, con fundamento en los siguientes

\section{HECHOS}

(Presente una relación detallada y clara de los hechos por los cuales se hace la petición):

1.

2.

3.

\section{RAZONES Y FUNDAMENTOS JURÍDICOS}

(Exposición argumentativa jurídica donde se evidencie la vulneración de los derechos):

\section{PRETENSIONES}

(Lo que solicita de manera clara, precisa y concreta).

\section{PRUEBAS}

(En este espacio se relacionan los documentos que sirven de soporte probatorio) 


\section{NOTIFICACIONES}

Dirección física, correo electrónico y teléfono donde se va a recibir la respuesta.

FIRMA DEL SOLICITANTE 


\section{DERECHO DE FAMILIA}

Por Germán Arturo Cardona Villa

\section{Resumen}

Este capítulo busca brindarle al lector ciertas directrices que le ayudarán a llevar a cabo sus asesorías con mayor capacidad de disertación. Se constituye además en una herramienta importante para saber cómo adentrarse en la materia sin dilaciones que entorpezcan su asesoría.

Palabras clave: demanda ejecutiva de alimentos, derecho civil, medidas cautelares, poder de demanda de alimentos, proceso de alimentos. 


\section{INTRODUCCIÓN}

En las asesorías jurídicas es muy recurrente que encontremos las solicitudes de iniciación de procesos ejecutivos de alimentos, por lo que debemos tener en cuenta que este es un proceso de carácter civil, y netamente se busca el pago de las cuotas atrasadas por parte del deudor, por lo que siempre es necesario que se indague si la persona a la que vamos a ejecutar tiene algo que se le pueda embargar, como bienes muebles o inmuebles, cuentas u algún derecho, porque si el deudor no tiene algo que se le pueda perseguir, la demanda no serviría de nada, ya que su objeto desaparecería.

\section{CONCEPTOS EN PROCESO DE ALIMENTOS}

El Código Civil ha establecido en el artículo 411 a quién se tiene la obligación alimentaria, y lo instituye de la siguiente manera:

Se deben alimentos:

1. Al cónyuge.

2. A los descendientes legítimos.

3. A los ascendientes legítimos.

4. A cargo del cónyuge culpable, al cónyuge divorciado o separado de cuerpo sin su culpa.

5. A los hijos naturales, su posteridad legítima y a los nietos naturales.

6. A los ascendientes naturales.

7. A los hijos adoptivos.

8. A los padres adoptantes.

9. A los hermanos legítimos.

10. Al que hizo una donación cuantiosa si no hubiere sido rescindida o revocada.
Por esta razón, y teniendo presente que estas consultas son las más recurrentes, en Consultorio Jurídico de la Universidad Cooperativa de Colombia se procede a generar una serie de documentos guía que permitirán a los abogados en formación ser más proactivos en su práctica.

\section{Conceptos: fijación de cuota alimentaria}

Como se ha visto, la obligación alimentaria recae sobre el padre o la madre que no convivan con el reclamante, además genera una responsabilidad que lo obliga a sacrificar parte de su propiedad con el fin de garantizar la subsistencia del acreedor de los alimentos.

Para que la obligación preste mérito ejecutivo, debe ser pactada por escrito por las partes (obligado a proporcionar alimentos, el acreedor de los alimentos y su representante legal si es el caso). Si existe voluntad de las partes, se puede hacer mediante documento privado suscrito en una notaría, o elevado antes un centro de conciliación, que bien puede ser el Consultorio Jurídico de la Universidad Cooperativa de Colombia, una Casa de Justicia, el Instituto Colombiano de Bienestar Familiar (ICBF), una Comisaría de Familia (todo ellos gratuitos), o en una Cámara de Comercio si se tiene capacidad de pago (véase capítulo "MASc: métodos alternativos de solución de conflictos").

Si no se tiene acuerdo conciliatorio, se debe acudir al ICBF o a una Comisaría de familia, instituciones que procederán a establecer una cuota de alimentos provisional, la cual deberá decir en últimas si es decisión de las partes solicitar que un juez de familia determine si es acorde a las necesidades del acreedor de los alimentos o debe ser aumentada o disminuida según sea el caso. Conviene recordar que los alimentos aumentan cada año según lo que se haya establecido en el acta de acuerdo (tabla 3); tal aumento puede ser fijado según el 
índice de precios al consumidor (IPC) o según el salario mínimo (si no está establecido será según el IPC).

Ya existiendo el documento que presta mérito ejecutivo, ya sea documento privado, acta de conciliación, resolución de alimentos o sentencia de alimentos elevada por un juez de la república, y al generarse un incumplimiento en el pago de las cuotas o en su incremento anual, el acreedor alimentario puede iniciar un proceso ejecutivo de alimentos, el cual busca la satisfacción o el pago de las cuotas atrasadas, a fin de garantizar el bienestar del acreedor.

\section{DEMANDA DE ALIMENTOS}

Para presentar una demanda de alimentos, se deben tener unos documentos indispensables para poder realizarla, como se muestra en los modelos al final de este capítulo.

\section{TABLA 3}

Actualización de aumento de cuota alimentaria

\begin{tabular}{|c|c|c|c|}
\hline \multicolumn{4}{|c|}{ Cuota año 2014: 250000} \\
\hline \multicolumn{4}{|c|}{ Aumento año 2015: 4,60\% } \\
\hline Mes & Valor cuota & Valor entregado & Valor adeudado \\
\hline Ene.-15 & 261500 & 0 & 261500 \\
\hline Feb.-15 & 261500 & 0 & 523000 \\
\hline Mar.-15 & 261500 & 0 & 784500 \\
\hline Abr.-15 & 261500 & 0 & 1046000 \\
\hline May.-15 & 261500 & 0 & 1307500 \\
\hline Jun.-15 & 261500 & 0 & 1569000 \\
\hline $\begin{array}{l}\text { Cuota adicional junio, entregada en cuotas mensuales adicionales } \\
\qquad \text { a la cuota de alimentos }\end{array}$ & 261500 & 0 & 1830500 \\
\hline Jul.-15 & 261500 & 0 & 2092000 \\
\hline Ago.-15 & 261500 & 0 & 2353500 \\
\hline Sep.-15 & 261500 & 0 & 2615000 \\
\hline 0ct.-15 & 261500 & 0 & 2876500 \\
\hline Nov.-15 & 261500 & 0 & 3138000 \\
\hline Dic.-15 & 261500 & 0 & 3399500 \\
\hline $\begin{array}{l}\text { Cuota adicional diciembre, entregado en cuotas mensuales } \\
\text { adicionales a la cuota de alimentos }\end{array}$ & 261500 & 0 & 3661000 \\
\hline \multicolumn{3}{|l|}{ Total adeudado 2015} & 3661000 \\
\hline
\end{tabular}

Nota: elaboración propia. 


\section{REFERENCIAS}

Actualícese. (2019, 18 de julio). Prima: ¿qué es?, ¿cómo se paga?, ¿hay sanciones por pago moroso? https:// bit.ly/3Fvmlym

Arenas Monsalve, G. (2008). El derecho colombiano de la seguridad social (2. ${ }^{\mathrm{a}}$ ed.). Legis.

Congreso de la República de Colombia. (1950). Decreto 2663 de 1950, Código Sustantivo del Trabajo. https:// bit.ly/3v6xwZx

Congreso de la República de Colombia. (1959). Ley 15 de 1959, por la cual se reconocen intereses anuales a las cesantías de los trabajadores particulares. https://bit.ly/3mLobm5

Congreso de la República de Colombia. (1975). Ley 52 de 1975, por la cual se reconocen intereses anuales a las cesantías de los trabajadores particulares. https://bit.ly/3Dw10TD

Congreso de la República de Colombia. (1990). Ley 50 de 1990, por la cual se introducen reformas al Código Sustantivo del Trabajo y se dictan otras disposiciones. https://bit.ly/2X2hIKO

Congreso de la República de Colombia. (1993). Ley 100 de 1993, por la cual se crea el sistema de seguridad social integral y se dictan otras disposiciones. https://bit.ly/3arOVUH

Congreso de la República de Colombia. (2000). Ley 583 de 2000, por la cual se modifican los artículos 30 y 9 del Decreto 196 de 1971. https://bit.ly/2YAaAWu

Congreso de la República de Colombia. (2015). Ley 1755 de 2015, por medio de la cual se regula el Derecho Fundamental de Petición y se sustituye un título del Código de Procedimiento Administrativo y de lo Contencioso Administrativo. https://bit.ly/3Bt6JZT

Congreso de la República de Colombia. (2016). Ley 1788 de 2016, por medio de la cual se garantiza el acceso en condiciones de universalidad al derecho prestacional de pago de prima de servicios para los trabajadores y trabajadoras domésticos. https://bit.ly/2X3hsv3

Congreso de la República de Colombia. (2018). Constitución Política de Colombia. Bogotá: Legis.

Corte Constitucional Colombiana. (2006). Sentencia C-823 de 2006, M. P.: Rodrigo Escobar Gil. https://bit. ly/3oQ4rQX

Corte Suprema de Justicia, Sala de Casación Laboral. (2011). Sentencia 36035 de 2001, M. P.: Luis Gabril Miranda Buelvas. https://vlex.com.co/vid/552629726

Corte Suprema de Justicia, Sala de Casación Laboral. (2018). Sentencia 40374 de 2018, M. P.: Rigoberto Echeverri Bueno. https://bit.ly/306vxZN

Corte Suprema de Justicia, Sala de Casación Laboral. (2018). Sentencia 57903 de 2018, M. P.: Giovanni Francisco Rodríguez Jiménez. https://bit.ly/2YO5Z3j

Cortés Hernández, O. I. (2007). Derecho de la seguridad social (3. ${ }^{a}$ ed.). Ediciones El Profesional.

Presidencia de la República de Colombia. (1991). Decreto 1127 de 1991, por el cual se reglamentan los artículos 3 y 21 de la Ley 50 de 1990. https://bit.ly/3luwfZ4

Presidencia de la República de Colombia. (1991). Decreto 2591 de 1991, por el cual se reglamenta la acción de tutela consagrada en el artículo 86 de la Constitución Política. https://bit.ly/3BxLRAx

Ridulfo, E. y Herrera, S. (2018). El control de legalidad y el principio de revisión de los actos administrativos. Opinión Jurídica, 1(1), 59-72. https://bit.ly/3v21deg

Vargas, C. M. (2010). Derecho laboral: manual teórico práctico. Ibáñez. 


\section{MINUTA DE PODER DE DEMANDA DE ALIMENTOS}

Señor:

JUEZ FAMILIA DE (Reparto)

E. S. D.

Ref.: Poder especial

Yo, ciudad, identificado(a) con Cédula de Ciudadanía n. ${ }^{\circ}$ mayor de edad, domiciliado(a) en esta en obrando en mi propio nombre y en representación de mi hijo(a) menor, , de años de edad, por medio del presen-

te escrito confiero poder especial, amplio y suficiente al/la señor(a) abogado(a) en ejercicio, identificado(a) con Cédula de Ciudadanía n. ${ }^{\circ}$ expedida en portador(a) de la Tarjeta Profesional n. ${ }^{\circ}$ , del Consejo Superior de la Judicatura, para que instaure DEMANDA DE EJECUTIVA DE ALIMENTOS en favor de mi hijo(a) y en contra de su padre, el señor , mayor de edad, identificado con la Cédula de Ciudadanía n.․

Declaro que las informaciones suministradas a mi apoderado son veraces, por lo que, en caso de su eventual desvirtuación, la responsabilidad consiguiente es mía en forma exclusiva y excluyente.

Mi apoderado queda facultado expresamente para presentar la demanda, solicitar medidas cautelares, conciliar, transigir, desistir, sustituir, renunciar, reasumir, recibir y cuanto en derecho sea necesario para el cabal cumplimiento de su mandato en los términos del artículo 77 del Código General del Proceso.

Sírvase, Señor Juez, reconocer personería a mi apoderado judicial para los efectos y dentro de los términos de este mandato.

Del Señor Juez,

C. C. de

Acepto,

C. C.

T. P. 


\section{MINUTA DE DEMANDA DE ALIMENTOS}

Señor

JUEZ DE FAMILIA DE (REPARTO)

E. S. D.

Yo, mayor de edad, identificado(a) con Cédula de Ciudadanía $n{ }^{\circ}$ de abogado(a) en ejercicio, portador(a) de la Tarjeta Profesional n. ${ }^{\circ}$ del Consejo Superior de la Judicatura, domiciliado y residente en esta ciudad, actuando en calidad de apoderado judicial de la Señora , mayor de edad, identificada con la Cédula de Ciudadanía $n .{ }^{\circ}$ de domiciliada y residente en , quien actúa en nombre y representación de sus menores hijos

$\mathrm{y}$ , me permito formular ante su despacho DEMANDA EJECUTIVA DE ALIMENTOS en contra del Señor mayor de edad, identificado con la Cédula de Ciudadanía n. ${ }^{\circ}$ , de domiciliado y residente en esta

ciudad, con fundamento en los siguientes

\section{HECHOS}

PRIMERO: Entre la Señora y el Señor existió una relación sentimental sin convivencia ni vínculo legal alguno.

SEGUNDO: De dicha relación nacieron los menores $\mathrm{y}$ el primero de ellos el día , contando a la fecha con años, y el segundo el día de , quien en el momento tiene años.

TERCERO: Mediante acta de conciliación, celebrada en la Comisaría de el día se pactó, entre otros aspectos, que el padre de los menores consignaría dentro de los primeros cinco (5) días de cada mes la cuota alimentaria, en la cuenta n. ${ }^{\circ}$ , del Banco , cuya titular es mi mandante Señora

CUARTO: El Señor viene incumpliendo sus obligaciones alimentarias para con los menores de la siguiente manera: 
Tabla de registro de incumplimiento de la obligación

\begin{tabular}{|c|c|c|c|}
\hline \multicolumn{4}{|c|}{ Cuota año 2014: 250000} \\
\hline \multicolumn{4}{|c|}{ Aumento año 2015: 4,60\% } \\
\hline Mes & Valor cuota & Valor entregado & Valor adeudado \\
\hline Ene.-15 & 261500 & 0 & 261500 \\
\hline Feb.-15 & 261500 & 0 & 523000 \\
\hline Mar.-15 & 261500 & 0 & 784500 \\
\hline Abr.-15 & 261500 & 0 & 1046000 \\
\hline May.-15 & 261500 & 0 & 1307500 \\
\hline Jun.-15 & 261500 & 0 & 1569000 \\
\hline $\begin{array}{l}\text { Cuota adicional junio, entregada en cuotas mensuales } \\
\text { adicionales a la cuota de alimentos }\end{array}$ & 261500 & 0 & 1830500 \\
\hline Jul.-15 & 261500 & 0 & 2092000 \\
\hline Ago.-15 & 261500 & 0 & 2353500 \\
\hline Sep.-15 & 261500 & 0 & 2615000 \\
\hline Oct.-15 & 261500 & 0 & 2876500 \\
\hline Nov.-15 & 261500 & 0 & 3138000 \\
\hline Dic.-15 & 261500 & 0 & 3399500 \\
\hline $\begin{array}{l}\text { Cuota adicional diciembre, entregado en cuotas } \\
\text { mensuales adicionales a la cuota de alimentos }\end{array}$ & 261500 & 0 & 3661000 \\
\hline \multicolumn{3}{|c|}{ Total adeudado 2015} & 3661000 \\
\hline
\end{tabular}

QUINTO: Que el acta de conciliación en mención contiene una obligación clara, expresa y exigible de pagar una suma líquida de dinero en cabeza del demandado.

\section{PRETENSIONES}

Con base en los anteriores hechos, solicito a su Despacho:

PRIMERA: Librar mandamiento ejecutivo en contra del Señor y a favor de mi poderdante Señora en su calidad de representante legal de sus menores hijos $\mathrm{y}$ , por la suma de correspondiente a las cuotas alimentarias que ha rehusado cancelar, como se indica en la tabla anterior.

SEGUNDA: Condenar al demandado a pagar los intereses moratorios sobre la suma adeudada, desde la fecha que se hizo exigible la obligación y hasta cuando se haga efectivo su pago totalmente.

TERCERA: Que se condene al demandado en los gastos, costas judiciales y agencias en derecho en la cuantía que señale el juzgado.

\section{DERECHO}

La presente demanda se fundamenta en los artículos 411 y siguientes y 1617 del Código Civil; en el artículo 24 de la Ley 1098 de 2006; el Código General del Proceso y demás normas concordantes. 


\section{PROCEDIMIENTO, COMPETENCIA Y CUANTÍA}

El proceso que debe adelantarse es el ejecutivo singular de mínima cuantía (o menor cuantía). Por la naturaleza del proceso, la vecindad de las partes y la cuantía, la cual estimo en \$ , es Usted competente para conocer de este proceso.

\section{PRUEBAS}

Solicito se tengan como pruebas los siguientes documentos:

1. Registro civil de nacimiento de los menores $\mathrm{y}$

2. Copia auténtica del acta de conciliación.

4. Solicitud sobre medidas cautelares.

(Y demás pruebas pertinentes, necesarias y útiles).

\section{ANEXOS}

Me permito anexar a la presente demanda, dos copias con sus correspondientes anexos, para archivo y traslado tanto al demandado como al Señor Defensor de Familia; los documentos indicados en el acápite de pruebas y poder a mi favor.

\section{NOTIFICACIONES}

Mi poderdante en la dirección de esta ciudad.

El demandado en la dirección de esta ciudad.

El suscrito en la Secretaría de su Despacho o en la dirección de esta ciudad.

Del Señor Juez,

Atentamente,

C. C. n. ${ }^{\circ}$ de

T. P. n. ${ }^{\circ}$

Elaborado por Germán Arturo Cardona Villa. 


\section{MINUTA DE MEDIDAS CAUTELARES POR DEMANDA DE ALIMENTOS}

Señor:

JUZGADO DE FAMILIA DE

(REPARTO)

E. S. D.

REFERENCIA:

DEMANDANTE:

DEMANDADO:

Cordial saludo:

Yo, mayor de edad, con domicilio en abogado(a) en ejercicio e identificado(a) como aparece al pie de mi correspondiente firma, obrando como apoderado(a) de la señora , demandante en el asunto de la referencia, por medio del presente documento respetuosamente solicito a su despacho decretar las siguientes MEDIDAS CAUTELARES con carácter de previas para que los efectos de la acción ejecutiva no sean ilusorios, así:

PRIMERO: Se decrete el embargo y secuestro de los dineros que, a cualquier título, por concepto de certificados de depósitos, cuentas corrientes, cuentas de ahorro, depósitos a la vista y cualquier suma de dinero que por cualquier concepto conjunta o separadamente tenga la parte demandada, el Señor , identificado con Cédula de Ciudadanía n. ${ }^{\circ}$ , con una o más per-

sonas de las siguientes entidades bancarias:

BANCO AGRARIO - BANCO CAJA SOCIAL - BANCO DAVIVIENDA - BANCO DE BOGOTÁ - BANCO DE OCCIDENTE - BANCO BBVA - BANCO POPULAR - BANCO AV VILLAS - BANCOOMEVA - BANCOLOMBIA.

Para que la anterior medida se haga efectiva, Señor Juez, se servirá oficiar a las entidades bancarias antes relacionadas.

Me reservo el derecho a denunciar otros bienes de propiedad del aquí demandado, de manera posterior, en el evento que las medidas solicitadas resultaren insuficientes.

Del Señor Juez,

Atentamente,

C. C. n. ${ }^{\circ}$

T. P. n. ${ }^{\circ}$

Elaborado por Germán Arturo Cardona Villa. 


\title{
DERECHO LABORAL Y SEGURIDAD SOCIAL
}

\author{
Por Andrés Fernando López Cruz
}

\section{Resumen}

Derecho Laboral Individual y Seguridad Social son cursos que se categorizan dentro de los derechos económicos, sociales y culturales (DESC). En este capítulo se presentará a los estudiantes de derecho, profesores e interesados una guía concreta sobre los principales aspectos de estas áreas, buscando que sea de utilidad para las asesorías del Consultorio Jurídico. Al mismo tiempo, se pretende que pueda ser usado para la materialización de diferentes elementos entregados a los usuarios, como los derechos de petición, las acciones de tutela, las liquidaciones de derecho laboral, las demandas ordinarias para procesos de única instancia, entre otros. Esta guía busca, en general, sustentar unas bases para una asesoría de derecho laboral individual o de seguridad social; no pretende ser la compilación de dos asignaturas del derecho, pues estas incorporan muchos más temas, tal como se evidencia en los programas en curso de la Universidad Cooperativa de Colombia; sin embargo, como se podrá apreciar en su contenido, podría ser muy útil en los estudios de pregrado de los cursos relacionados con la temática acá desarrollada una buena forma de dar una introducción o un complemento.

Palabras clave: contrato de trabajo, derecho laboral, liquidaciones laborales, prestaciones sociales, salario, seguridad social. 


\section{INTRODUCCIÓN}

Este capítulo relacionado con el derecho laboral y la seguridad social pretende principalmente entregar a los estudiantes algunas herramientas teóricas y prácticas que puedan ser utilizadas en las asesorías y en la proyección de documentos que se les asignen durante su estancia en el Consultorio Jurídico de la Universidad. Esta guía además puede ser utilizada por estudiantes, profesores y egresados de las facultades de Derecho en la enseñanza y el aprendizaje de esta área del conocimiento del mundo jurídico, especialmente cuando se trabajen temas relacionados con la liquidación de los derechos laborales.

En este capítulo, el lector encontrará un desarrollo básico del derecho laboral individual y de la seguridad social; se enfoca en una explicación concreta con desarrollo en ejercicios prácticos, buscando establecer parámetros generales en cuanto a la figura del contrato de trabajo y las obligaciones que tienen las partes en medio de este acto jurídico. Se presentan los conceptos relacionados con cada uno de los derechos laborales y la cuantificación de estos con base en diferentes ejercicios hipotéticos. Se entregan además fórmulas que serán de gran utilidad a la hora de asociar un caso real para desarrollar valores de cada uno de estos conceptos.

Este trabajo se desarrolla conforme a una metodología mixta, teniendo presente que, además de describir y explicar los conceptos básicos de las relaciones labores, estos también se van a cuantificar conforme a fórmulas matemáticas. Se presentó un desarrollo de método deductivo partiendo de un estudio documental con fuentes secundarias, para posteriormente, y con base en ejercicios hipotéticos creados por el mismo autor, llegar a resoluciones particulares.
CONCEPTOS Y LIQUIDACIONES DE DERECHO LABORAL INDIVIDUAL Y SEGURIDAD SOCIAL

\section{Conceptos generales}

\section{CONCEPTO DE DERECHO LABORAL Y ELEMENTOS DEL CONTRATO DE TRABAJO}

El derecho laboral individual surge con la finalidad de regular las relaciones entre el trabajador y el empleador, buscando un equilibrio económico entre ambas partes y una convivencia pacífica en sus relaciones laborales surgidas a través de la figura del contrato de trabajo. El trabajo es un derecho fundamental reconocido desde la Constitución Política de 1991 en artículos como el 25 y 53; el derecho laboral individual es regulado para el sector privado en el Código Sustantivo del Trabajo. El trabajo genera para las personas un reconocimiento social y, al mismo tiempo, unas garantías protectoras en favorabilidad para los trabajadores.

El derecho laboral tiene su base en el contrato de trabajo, el cual tiene lugar cuando existen tres elementos regulados por el mismo Código Sustantivo de Trabajo en el artículo 23: 1) la prestación personal del servicio, 2) la subordinación y 3) la remuneración. Asimismo, dentro del contrato de trabajo aparecen diferentes aspectos, como las modalidades de contratos, las obligaciones de las partes, las prohibiciones, las formas de terminar el contrato, el periodo de prueba, las prórrogas, el reglamento interno de trabajo, etc.

\section{CONCEPTO DE SEGURIDAD SOCIAL DESDE LA CONSTITUCIÓN Y DESDE LA LEY 100 DE 1993}

El concepto de seguridad social es de reciente creación y proviene de uno anterior conocido 
como la previsión social, entendido como "la acción de disponer lo conveniente para atender contingencias o necesidades previsibles de la sociedad" (Cortés Hernández, 2007, p. 3). El concepto de seguridad social ha tenido como protagonismo el principio de solidaridad, desde el entendido de que las personas con mayor fuerza económica son quienes más deben contribuir a la protección de las necesidades de quienes no tienen ese beneficio.

La seguridad social es implementada, desde el Estado social de derecho, como una garantía para la calidad de vida de las personas que lo componen. Este derecho establece auxilios económicos y atenciones en salud de forma permanente, tal como se desprende del artículo 7 de la Ley 100 de 1993, o Ley General de la Seguridad Social en Colombia. La concepción más sencilla de la seguridad social es que el ciudadano se encuentre en las mejores condiciones de vida; así es establecida desde el artículo 48 de la Constitución de 1991 y en la Ley 100 de 1993 (preámbulo y artículo 1).

El derecho a la seguridad social protege las necesidades de los seres humanos reconocidas como contingencias, dentro de las cuales se pueden mencionar las alteraciones a la salud, las incapacidades para trabajar, la muerte, la invalidez, la vejez y el desempleo. Estas contingencias mencionadas ponen en un individuo una carga adicional que puede ser insoportable de resistir; precisamente esa necesidad requiere la atención desde la seguridad social con diferentes prestaciones como la asistencia médica, el pago de incapacidades, la prestación de desempleo, las prestaciones por vejez, las prestaciones por invalidez, las prestaciones por muerte, las prestaciones por maternidad, entre otras (Arenas Monsalve, 2008).

La seguridad social es regulada como un derecho irrenunciable y un servicio público obligatorio ${ }^{13}$ prestado por el Estado para sus asociados;

13 El artículo 4 de la Ley 100 de 1993, en armonía con el artículo 48 de la Constitución, cataloga a la seguridad social como consiste en proteger a las personas de contingencias que son comunes durante su vida o en el tiempo que ejecutan sus labores. La seguridad social es un servicio público esencial para la salud y para el reconocimiento y pago de pensiones. Igualmente, la seguridad social puede ser prestada por particulares o por entidades públicas; sin embargo, la dirección, organización y control son funciones exclusivas del Estado (arts. 4 y 5 de la Ley 100 de 1993).

De acuerdo con el artículo 6 de la Ley 100 de 1993, dentro de los objetivos la seguridad social, esta debe cubrir no solo a las personas que pueden contribuir al sistema, es decir, quienes tienen una relación de trabajo ${ }^{14}$, sino además a las personas que no lo pueden realizar por encontrarse en situaciones de desempleo o empleos informales.

\section{Componentes del Sistema Integral de Seguridad Social}

El Sistema Integral de Seguridad Social se compone de forma armónica de diferentes entidades $^{15}$, normas y procedimientos. De acuerdo con el inciso 2 del artículo 1 y el artículo 8 de la Ley 100 de 1993, la seguridad social está compuesta de la siguiente forma:

1. Sistema General de Pensiones. Lo integran dos regímenes: el de prima media, con prestación definida administrada por Colpensiones, y el de ahorro individual con solidaridad, que lo administran varias empresas del sector privado, como Colfondos, Porvenir, etc. La cotización en pensión en las relaciones laborales es asumida por el empleador

servicio público obligatorio, cuya dirección, coordinación y control está a cargo del Estado.

14 Se entiende relación de trabajo como aquella en la cual una persona natural obtiene beneficios económicos como resultado de una actividad desarrollada, llámese independiente, contratista, cooperado o trabajador.

15 Dentro de las entidades, se pueden mencionar las entidades promotoras de salud, los fondos de pensiones, las juntas de calificación de invalidez, entre otras. 
y el trabajador en conjunto; de la cotización se paga el $75 \%$ por el empleador y el $25 \%$ por el trabajador, valor que se le descuenta del salario. En la actualidad, el valor a cotizar se extrae del 16\% del salario base o mensual devengado por el trabajador.

2. Sistema General de Seguridad Social en Salud. También está compuesto por dos regímenes: contributivo y subsidiado. Está administrado por entidades públicas y por el sector privado. La cotización, igual que en la pensión, es pagada en su mayoría por el empleador en las relaciones laborales. En salud, se debe cotizar el $12,5 \%$ del salario base o mensual devengado por el trabajador; de este, el empleador cotiza el 8,5\% y el trabajador pagará el restante $4 \%$. La salud ha sido un derecho comúnmente reclamado mediante acción de tutela, argumentando la salud como un derecho fundamental, tal como quedó establecido en la Ley 1751 de 2015, o Ley Estatutaria. Adicionalmente, al revisar el artículo 86 de la Constitución de 1991 y el Decreto 2591 de 1991, se encuentran fundamentos para que este derecho pueda ser efectivo a través del mecanismo constitucional de la acción de tutela, principalmente al considerar la inexistencia de un mecanismo que pueda proteger el derecho de forma sumaria, como se requiere en esta clase de derecho, y así evitar un perjuicio irremediable.

3. Riesgos laborales. Relacionados con las contingencias que se presentan dentro de las actividades de trabajo, catalogadas como accidentes de trabajo o enfermedades laborales. En la relación laboral, el cotizante es el empleador en el $100 \%$ de la cotización; al igual que en pensiones y salud, la cotización se extrae del salario base o mensual. La cotización en los riesgos laborales depende de la clase de riesgo en que se encuentre catalogada la actividad de trabajo de quien se afilia; actualmente se cuentan cinco clases de riesgo.
4. Servicios complementarios. Estos servicios son regulados desde el artículo 257 de la Ley 100 de 1993, que busca en general proteger a los ancianos indigentes que no lograron el acceso a prestaciones económicas del Sistema de Seguridad Social, y además no cuentan con ingresos económicos de otra naturaleza. En el artículo 262 de la Ley 100 de 1993 se establece además una proyección de otro servicio complementario: un subsidio al desempleo.

\section{CLASES Y MODALIDADES DEL CONTRATO DE TRABAJO}

\section{Según su forma (art. 37 CST)}

\section{VERBAL (ART. 38 CST)}

Es realizado de manera verbal ante las órdenes de un empleador sin ninguna formalidad, es decir, no hay un contrato escrito. Sin embargo, se genera una relación laboral por este contrato y, por ende, el cumplimiento de todas las obligaciones relacionadas con este vínculo. Para que se produzca contrato verbal, las partes deben ponerse de acuerdo con, al menos, en los siguientes puntos: índole de trabajo, sitio de trabajo, cuantía, forma de remuneración, periodo en que se efectúa el pago y duración del contrato. Los contratos verbales tienen el mismo valor que los escritos. Es importante hacerlos por escrito por temas probatorios; sin embargo, como se mencionó previamente, el contrato verbal exige las mismas obligaciones que uno escrito en cuanto a pago de salario, prestaciones sociales y seguridad social (Legis, 2014, p. 35).

\section{ESCRITO (ART. 39 CST)}

Es escrito cuando a través de un documento de cualquier naturaleza se materializa la voluntad de iniciar una relación laboral, de 
conformidad con el Código Sustantivo de Trabajo; deberá contener: nombre e identificación de las partes, domicilio de las partes, lugar y fecha de celebración, lugar donde se contrata al trabajador, naturaleza del contrato, cuantía de la remuneración, forma, periodos de pago y duración del contrato.

\section{TÁCITO}

Se genera contrato tácito cuando entre el empleador y el trabajador no se ha manifestado una intención de generar una relación laboral, es decir, hay un silencio de las partes, pero por las acciones que se dan en determinado periodo, tendientes a cumplir funciones, en horarios establecidos y bajo un pago, se configura el contrato de trabajo atendiendo a sus elementos esenciales.

\section{Según su duración o modalidad (art. 45 CST)}

\section{FIJO (ART. 46 CST Y ARTS. 1 Y 2 DEL DECRETO 1127 DE 1991]}

La característica principal del contrato fijo es la duración definida por ambas partes; por tanto, trabajador y empleador conocen la fecha de inicio y de terminación de la relación laboral. El contrato a término fijo exige como formalidad que se pacte por escrito; según la Corte Suprema de Justicia en Sala de Casación Laboral, en Sentencia 36035 de 2011, es el término del contrato el que debe quedar establecido por escrito, por lo que el resto de las cláusulas pueden ser verbales.

El contrato fijo se prorroga de forma automática ante el silencio de las partes; la prórroga del contrato se realiza por el mismo término que el contrato inicial de forma indefinida ${ }^{16}$.

16 Un contrato fijo no se convierte en indefinido en ningún momento; lo indefinido en este contrato son sus prórrogas, pero el término siempre será definido, como se ha explicado.
Sin embargo, cuando el contrato a término fijo se pacta por un término inferior a un año, las prórrogas tienen un comportamiento diferente. En ese caso, las tres primeras prórrogas son por el mismo periodo del contrato inicial, y a partir de la cuarta prórroga se deberá dilatar mínimo por un año.

\section{Ejemplo}

1. El contrato de Luis fue pactado por un término de tres meses, inició desde el 13 de mayo de 2016 y fue despedido sin justa causa el 5 de octubre de 2.021, teniendo en cuenta esta fecha de despido, ¿hasta qué fecha estuvo vigente el contrato de trabajo de Luis como para pensar en la indemnización por despido sin justa causa que contempla el artículo 64 del C.S.T.?

Los periodos del contrato de Luis serían:

1. Periodo de inicio del contrato: del 13 de mayo de 2016 hasta el $12^{17}$ de agosto de 2016.

2. Primera prórroga: del 13 de agosto de 2016 hasta el 12 de noviembre de 2016.

3. Segunda prórroga: del 13 de noviembre de 2016 hasta el 12 de febrero de 2017.

4. Tercera prórroga: del 13 de febrero de 2017 hasta el 12 de mayo de 2017.

5. Cuarta prórroga ${ }^{18}$ : del 13 de mayo de 2017 hasta el 12 de mayo de 2018.

Las prórrogas siguientes se mantendrán por un año indefinidamente, siempre y cuando permanezca el silencio de las partes; por ende, en

17 En ejercicios de derecho laboral individual, siempre al contar en meses o años, se debe disminuir un día de un mes a otro o de un año a otro; de no hacerlo se estarían contando tres meses y un día en el ejemplo planteado.

18 De conformidad con lo mencionado, y al ser un contrato con periodo inferior a un año, esta cuarta prorroga será de un año ante el silencio de las partes. 
el ejemplo de Luis, el contrato estuvo vigente hasta el 12 de mayo de 2022.

El contrato fijo que se realice de forma verbal se entenderá como un contrato a término indefinido, así se deje un término de duración claro, pero de forma verbal; es decir, que siempre que un contrato tenga un término de finalización válido, este debe quedar por escrito, ya sea en el mismo contrato o en un documento diferente. Así se estableció en sentencia de la Corte Suprema de Justicia del 16 de diciembre de 1956 (Vargas, 2010, p. 59).

El término del contrato a término fijo podrá ser desde un día y no podrá ser superior de tres años, pero es renovable indefinidamente ante el silencio de las partes; así el término de esta modalidad de contrato o de cualquier otra sea de un día o de horas, los trabajadores siempre tienen derecho al pago de sus acreencias laborales mínimas (salario, prestaciones sociales, vacaciones y seguridad social).

El empleador puede dar por finalizado el contrato fijo a través de la figura del preaviso; consiste en una comunicación al trabajador informando que su contrato no se dará por prorrogado o que finalizará en la fecha del término final. Este preaviso debe realizarse por lo menos con 30 días de anticipación a la fecha en que terminaría el contrato. En los contratos a término fijo con duración inferior a treinta días, no se requiere preaviso para su terminación. En sentencia con radicado 40374 de 2018 se ha manifestado, respecto al preaviso, "que el término de 30 días es continuo sin excluir los días no hábiles".

La Corte Suprema de Justicia, en Sala de Casación Laboral, sentencia con radicado 35902 del 2009, ha manifestado que se puede terminar el contrato de trabajo sin dar preaviso cuando se va a cambiar la modalidad del contrato de trabajo, y que continuará la relación laboral siempre que se respete el principio de la estabilidad laboral. El contrato a término fijo no exige prueba ad probationem, que es cuando la ley exige determinada prueba para cierto acto jurídico como el certificado de defunción para probar la muerte, siendo entonces prueba ad sustanciam actus, es decir, que se puede probar por cualquier medio de prueba.

\section{INDEFINIDO (ART. 47 CST)}

Como puede desprenderse de la denominación, esta modalidad de contrato de trabajo no tiene una duración establecida, es decir, las partes conocen el inicio de la relación laboral pero no la fecha de terminación. De conformidad con el Código Sustantivo de Trabajo, el contrato indefinido perdura mientras se estén generando las causas por las que se le dio origen al contrato. Es reconocido como un contrato residual a las demás modalidades; esto significa que, ante el silencio de las partes, se entiende que el contrato es indefinido y puede celebrarse de forma verbal o escrita.

El contrato indefinido es residual respecto a los otros contratos de trabajo y así es entendido desde el inciso primero del artículo 47, que manifiesta que siempre que no se establezca término de finalización de un contrato, que se realice de forma verbal y que no quede estipulado como contrato de obra o labor determinada u ocasional, se considerará como un contrato a término indefinido. Además, con base en la primacía de la realidad sobre las formalidades, establecida de forma directa en el artículo 53 de la Constitución Política y de forma indirecta en el 22 y ss. del Código Sustantivo del Trabajo, el vínculo o contrato que, siendo de otra naturaleza y cumpla con los elementos de una relación laboral, deberá ser declarado bajo la modalidad de contrato indefinido, teniendo en cuenta que no se ha establecido dentro del contrato que disfraza la relación laboral, de forma escrita, un término de finalización con características de contrato a término fijo o de otra naturaleza. 


\section{CONTRATO DE OBRA O LABOR DETERMINADA} [ART. 45 CST] ${ }^{19}$

A diferencia del contrato fijo, cuya duración queda establecida por las partes con su acuerdo de voluntades, en esta modalidad la duración del contrato es determinada por el tiempo que dure determinada obra o labor; de tal suerte, terminada esta, se finalizado el contrato. Además, este contrato no admite la prórroga que tiene el contrato a término fijo y lo caracteriza la determinación clara de la obra o la labor que se va a realizar.

Se puede realizar de manera verbal o escrita, pero es recomendable efectuarlo por escrito, para determinar de forma clara en qué consiste la obra por realizar o la labor. Es un contrato comúnmente utilizado en obras civiles o en cargos relacionados con una labor que se puede cuantificar en cuanto al objeto de esta. Ejemplo de este contrato sería el contrato de trabajo, mediante el cual se paga un salario mínimo mientras se termina con la construcción de un inmueble; otro ejemplo puede ser pagar un salario mientras se realiza por parte de un trabajador un artículo de investigación en nombre de una universidad. Lo importante, como ya se ha mencionado, es determinar de forma clara el objeto de la obra y labor, de tal suerte que terminada esta, se extingue la relación laboral. En el contrato de obra o labor determinada se deben reconocer todos los derechos laborales, prestacionales y de seguridad social durante el término que dure el contrato de trabajo; esta es una característica común en todas las modalidades de contrato de trabajo e incluso en el periodo de prueba de estos.

\section{CONTRATO OCASIONAL O TRANSITORIO [ART. 6 CST]}

El contrato de trabajo es ocasional cuando la labor es diferente a la realizada por la empresa

19 Recomiendo consultar este enlace para ampliar el tema: https:// bit.ly/3BDKBfq en su objeto social y es de corta duración, no mayor de un mes. Lo que hace ocasional el contrato de trabajo no es la frecuencia con la que el trabajador labore, sino la naturaleza y las características propias de la actividad. En el contrato ocasional se deben de pagar las prestaciones sociales y seguridad social al trabajador en proporción al tiempo en el cual prestó sus servicios personales, así ha sido mencionado por la Corte Constitucional en Sentencia C-825 de 2006, donde se mencionó que excluir prestaciones sociales como las cesantías sería excluir el principio de universalidad que tienen estas acreencias laborales.

Vargas (2010), en su obra de derecho laboral, de forma errada expone que los trabajadores ocasionales no tienen el derecho a prestaciones sociales, a seguridad social, a vacaciones y a otros derechos de carácter laboral, al manifestar:

Los empleados contratados para realizar trabajos de carácter ocasional, accidental o transitorio no tienen derecho al pago de cesantías, prima de servicios, vacaciones, calzado y vestido de labor, además se encuentran excluidos de la obligación del empleador de afiliarlos al Sistema de Seguridad Social, esto es, pensiones, salud y riesgos profesionales. (p. 69)

Considera la autora que esta clase de contratos no están sometidos a la legislación laboral y realiza una exclusión al considerar que están haciendo labores diferentes a la naturaleza del empleador. De tomarse como ciertas dichas afirmaciones, se generaría desigualdad en las relaciones laborales y además se dejaría una herramienta muy peligrosa con la cual se desconocerían relaciones laborales. Clara es la Corte Constitucional, en la Sentencia C-823 de 2006, al otorgar todos los beneficios laborales, en igualdad de condiciones, a los trabajadores ocasionales. Como conclusión, el trabajador ocasional tiene los mismos beneficios de un trabajador con otra clase de contrato, y por eso es un contrato de trabajo y no de otra naturaleza. 


\section{SALARIO}

\section{Concepto y salario mínimo}

El tercer elemento de un contrato de trabajo consiste en un derecho económico que beneficia al trabajador como contraprestación a los servicios prestados. El salario se reconoce en proporción al tiempo trabajado y no puede desconocer los límites legales o convencionales. Hay que tener en cuenta que el salario mínimo puede ser legal o puede ser convencional; el primero acordado por el Gobierno Nacional y el segundo cuando en determinadas empresas lo acuerdan bajo un contrato especial. El salario mínimo legal, al igual que el auxilio de transporte ${ }^{20}$, son actualizados cada año por el Gobierno; en los últimos años ha sido actualizado como se muestra en la tabla 5.

\section{TABLA 5}

Actualización de smm/v

\begin{tabular}{|c|c|c|}
\hline Año & Salario mínimo & Auxilio de transporte \\
\hline 2021 & 908526 & 106454 \\
\hline 2020 & 877803 & 102854 \\
\hline 2019 & 828116 & 97032 \\
\hline 2018 & 781242 & 88211 \\
\hline 2017 & 737717 & 83140 \\
\hline 2016 & 689455 & 77700 \\
\hline 2015 & 644350 & 74000 \\
\hline 2014 & 616000 & 72000 \\
\hline 2013 & 589500 & 70500 \\
\hline 2012 & 566700 & 67800 \\
\hline 2011 & 535600 & 63600 \\
\hline 2010 & 515000 & 61500 \\
\hline 2009 & 496900 & 59300 \\
\hline 2008 & 461500 & 55000 \\
\hline 2007 & 433700 & 50800 \\
\hline 2006 & 408000 & 47700 \\
\hline
\end{tabular}

Nota: tomado de Gerencie.com (2021).

20 Este derecho se reconoce a los trabajadores que devengan menos de dos salarios mínimos y que no viven dentro de su lugar de trabajo; busca contribuir al desplazamiento del trabajador de su residencia hacia el trabajo. Para más información, revisar el siguiente enlace: https://www.gerencie.com/auxilio-de-transporte.html

\section{Factores salariales y factores no salariales}

Es indispensable tener en cuenta que hay dos clases de salario: el básico y el mensual o base. El salario básico lo constituye el monto acordado entre las partes en el contrato de trabajo, mientras que el salario mensual es constituido por el salario básico y por otros factores que sean salariales, como horas extras o comisiones. Por lo anterior, es importante reconocer qué pagos constituyen salario y qué pagos no. Esta diferencia es indispensable para poder liquidar al trabajador en prestaciones sociales, vacaciones, indemnizaciones y hasta cotizaciones de seguridad social.

En el artículo 127 del cst se establecen los factores que son salariales, en tanto en el artículo 128 se estipulan los factores que no son salariales. De forma general, lo que se derive de la prestación del servicio y que sean pagos habituales son salario, independientemente del nombre que se les dé, como primas, bonificaciones, comisiones, sobresueldos, viáticos, entre otros. Por el contrario, no forma parten del salario los pagos que no son habituales, que son por mera liberalidad del empleador, los pagos que no son para retribuir el trabajador sino para su desempeño, como las herramientas de trabajo, las prestaciones sociales o los pagos que, según estas características, son expresados por escrito como pagos no salariales.

Hay otras disposiciones legales que se salen de las características generales señaladas para lo que es o no es salario. Es así como se establece que las propinas no serán salario (así sean pagos continuos), igual sucede con los viáticos de transporte y con los viáticos para gastos de representación, que no son considerados como salario así sean pagos constantes. Las horas extras o trabajo suplementario y las comisiones siempre son consideradas como salario, así no haya constancia del pago de estas; respecto a las comisiones, cabe tener en cuenta la Sentencia 57903 de 2018 de la Corte Suprema de Justicia 
en Sala de Casación Laboral (Corte Suprema de Justicia Sala de Casación Laboral, 2018).

Un ejemplo para el tema sería: Joan Santos recibe como pagos en el 2018 los siguientes: un salario básico de $\$ 1100000$; en el mes de febrero y marzo, por horas extras, $\$ 220000$ en cada mes; recibió en diciembre un bono de navidad de \$150000; cada mes recibía de viáticos de transporte $\$ 55000$, así como viáticos de alojamiento de $\$ 70000$; y recibió en el mes de marzo \$35000 en comisiones. De este ejemplo se podría decir que los factores salariales serían su salario básico, las horas extras, los viáticos de alojamiento y las comisiones; los otros pagos no son constitutivos de salario.

\section{Ejercicio sobre factores salariales}

El señor Diego Cruz, durante la relación laboral que duró entre el 4 de febrero de 2017 y el 7 de mayo de 2019, tuvo los siguientes pagos:

- Propinas: \$85000 cada mes.

- Viáticos de gastos de representación: $\$ 100000$ cada dos meses.

- Viáticos de alojamiento: \$70000 en los meses de enero y septiembre de 2018

- Viáticos de alimentación: \$30000 quincenales

- Comisiones: \$250000 cada mes.

- La salario básico era de: \$1.450.000

- Le pagaron como prima de servicio cuando finalizó el contrato: $\$ 450000$

- Horas extras nocturnas: \$100000

Marque una S dentro del paréntesis de cada concepto para los pagos que considere factores salariales.

\section{PRESTACIONES SOCIALES MÍNIMAS Y DERECHO A VACACIONES}

Dentro de los derechos mínimos e irrenunciables de los trabajadores, encontramos estos conceptos económicos, garantías de beneficio social para todos los trabajadores en Colombia. Cada uno de estos conceptos conlleva una finalidad establecida por las normas y que justifica el pago de estos; son pagos adicionales al salario y a las cotizaciones del sistema de seguridad social.

De conformidad a las normas ${ }^{21}$ que regulan estos derechos sociales, se reconocen y pagan en diferentes fechas del año, como se verá más adelante. Esto siempre que el vínculo laboral se mantenga vigente; en caso de que el contrato finalice, se debe liquidar proporcionalmente al tiempo trabajado por el trabajador. En caso de que no hayan sido reconocidas durante la relación laboral, deben ser liquidadas al esta finalizar en proporción al tiempo trabajado y con el último salario devengado por el trabajador cuando su salario corresponde al salario mínimo; en caso de ser superior al salario mínimo, deberá realizarse una indexación sobre el salario que devengaba el trabajador.

\section{Vacaciones (art. 186 y ss. del csT)}

Es un derecho social de descanso en cuanto a dos elementos del contrato de trabajo: la prestación personal de servicio y la subordinación. En cuanto a la remuneración, se mantiene constante durante este descanso. Las vacaciones no son una prestación social, son un derecho que se le otorga al trabajador con la finalidad de que descanse por las labores realizadas. El descanso otorgado por vacaciones se concede al año de realizar los servicios y es

21 Código Sustantivo de Trabajo a partir del artículo 193, Ley 50 de 1990, Ley 52 de 1975, entre otras. 
de 15 días hábiles por cada año. Para los trabajadores que trabajan con la lucha de la tuberculosis o en rayos $\mathrm{X}$, el periodo de vacaciones es de 15 días hábiles por cada 6 meses de trabajo. En caso de terminación de contrato de trabajo sin disfrutar vacaciones, el empleador deberá liquidar el derecho con base en la siguiente fórmula:

Salario básico × Días trabajados

720

\section{Forma de remuneración}

El trabajador recibirá durante el periodo de vacaciones el salario que estuviese devengando hasta el momento de disfrutar de estas, excluyendo el pago de horas extras o de trabajos en día de descanso. Si el salario es variable, las vacaciones se liquidarán con el promedio del salario del último año.

\section{EJERCICIO PRÁCTICO}

Diego Cruz estuvo vinculado mediante contrato de trabajo a término indefinido con el señor Luis Durango. Diego no ha recibido vacaciones durante el tiempo que trabajo con Luis; estuvo trabajando desde el 24 de abril de 2019 hasta el 29 de septiembre de 2021, devengó como salario básico $\$ 920000$, recibió por horas extras \$80000 mensuales, propinas de $\$ 45000$ en promedio por el último año y viáticos de alojamiento cada mes de $\$ 140000$.

Solución: Para desarrollar el ejercicio, seguiremos los siguientes pasos:

1. Realizar una resta laboral: teniendo en cuenta la fórmula descrita, es necesario conocer el número total de días trabajados; lo recomendable es realizar la resta laboral. Los pasos son:

1.1. Se coloca la fecha mayor en la parte superior y la fecha menor en la parte in- ferior. La fecha mayor es la más actual. Se escribe primero el dato de año, luego mes y día; se comienza restando de derecha a izquierda, primero días, luego meses y posteriormente años:

\begin{tabular}{ccc} 
Año & Mes & Día \\
2021 & 09 & 29 \\
2019 & 04 & 24 \\
\hline 2 & 5 & $5+1$
\end{tabular}

(En días, siempre se debe sumar 122). Después de obtener estos resultados, como lo que se requieren son días, hay que convertir los meses a días, al igual que los años; para esto hay que tener en cuenta que en los ejercicios de derecho laboral un mes equivale a 30 días y un año a 360 días. Para finalizar, se suman lo días de esas operaciones, se desarrolla de la siguiente forma:

$$
\begin{array}{ll}
\text { Años: } & 2 \times 360=720 \\
\text { Meses: } & 5 \times 30=150 \\
\text { Días: } & 5+1=6
\end{array}
$$

\section{Total de días: 876 días}

Con este valor, ya podemos terminar el ejercicio ubicando los datos en la fórmula mencionada:

Salario básico $\times$ Días trabajados

$$
720
$$

$$
\$ 920000^{23} \times 876 / 720=\$ 1119333,33
$$

La solución para el caso sería: Diego tiene derecho a que se le reconozca como valor de vacaciones la suma de $\$ 1119333,33$

22 En estos ejercicios de contar días trabajados, siempre se debe sumar, en la primera resta de días, una unidad (solo en la resta de días).

23 Se escribe no más el salario básico, teniendo en cuenta los conceptos señalados. 


\section{AUXILIO DE TRANSPORTE}

El derecho a auxilio de transporte tiene la finalidad de otorgar una ayuda económica en el desplazamiento de los trabajadores desde sus residencias hasta el lugar de trabajo. Fue creado con la Ley 15 de 1959 y se reconoce a los trabajadores que devengan como salario básico un valor inferior a dos SMLMV. El auxilio de transporte es actualizado cada año por el Gobierno Nacional, tal como fue descrito en páginas anteriores; en el 2021 este auxilio corresponde al valor de $\$ 106454$, se paga mensualmente en proporción al tiempo laborado por el trabajador.

El auxilio de transporte no constituye un factor salarial debido a que su naturaleza es contribuir a un gasto de desplazamiento y no se relaciona con una contraprestación a los servicios prestados por el trabajador; sin embargo, este derecho sí debe ser tenido en cuenta para la liquidación del auxilio de cesantías, de la prima de servicios y de los intereses a las cesantías (Gerencie, 2021). Es así como debe sumarse para la liquidación de estas prestaciones sociales al salario base; claro está, haciendo la claridad que se tendrá en cuenta para aquellos trabajadores que tienen derecho a este auxilio según lo que se ha mencionado.

\section{DOTACIÓN DE CALZADO Y VESTIDO DE LABOR (ARTS. 230 Y SS. CST)}

Está regulada por los artículos 230 y ss. del Código Sustantivo de Trabajo. Esta prestación social a cargo del empleador se reconoce a los trabajadores que devengan hasta dos salarios mínimos. Consiste en otorgar a los trabajadores un pago en especie relacionado con el vestuario de trabajo; procede cada cuatro meses entregando un vestido y un calzado de labor. Para ser acreedor de este derecho, el trabajador debe llevar un mínimo de tres meses de prestación de servicios.
El cst no establece un valor relacionado con este pago en especie, pero sí debe ser acorde con la labor realizada y con las condiciones en que se trabaja, como el clima en que se desarrollan las funciones y actividades. Las fechas máximas de plazo para entregar la dotación son el 30 de abril, el 31 de agosto y el 20 de diciembre.

La dotación es totalmente diferente a los elementos de protección personal; estos últimos son derechos de todos los trabajadores, independientemente del salario que devenguen; se otorgan para la seguridad y salud en el trabajo de estos. Al respecto, el Ministerio de Salud y Protección Social (2017) los ha definido de la siguiente forma: "Todo equipo, aparato o dispositivo especialmente proyectado y fabricando para preservar el cuerpo humano, en todo o en parte, de riesgos específicos de accidentes de trabajo o enfermedades profesionales" (p. 3).

\section{AUXILIO DE CESANTÍAS (ARTS. 249 Y SS. CST)}

Esta prestación social tiene como finalidad principal servir de recurso al trabajador en situación de desempleo, por lo que la principal causa para solicitar estos ingresos se genera con la terminación definitiva del contrato de trabajo, lo cual se conoce como pago de cesantía totales. Con este auxilio económico se protege el mínimo vital y móvil del trabajador mientras este consigue un nuevo empleo. Las cesantías también pueden ser reclamadas para educación y vivienda por los trabajadores o para beneficio de sus familiares bajo esas dos finalidades ${ }^{24}$. En estas últimas causas, el pago del auxilio se denomina como parcial, pues el contrato de trabajo aún continúa vigente. Se reconoce al trabajador como valor de este derecho un salario mensual o base por

24 Otra de las causas para pago del derecho es ante el llamamiento del Estado a servicio militar obligatorio. En este caso es un pago parcial, pues el contrato de trabajo queda suspendido y no terminado, de conformidad al artículo 51 del cST. 
cada año trabajado o en proporción al tiempo en que lo haya hecho.

Desde la Ley 50 de 1990, se obligó a las empresas a depositar el auxilio de cesantías a un fondo especial y protector, y se debe consignar el pago de forma anualizada. Deben de ser liquidadas al terminar cada año y consignadas en el fondo de cesantías máximo hasta el 14 de febrero del año siguiente al que se hacen exigibles.

Ejemplo: al trabajador que cumplió su periodo laboral desde el 10 de mayo del 2019 y que aún sigue trabajando con la misma empresa se le debieron consignar las cesantías del año 2019 máximo hasta el 14 de febrero del 2020, pagándole el periodo desde el 10 de mayo del 2019 hasta el 31 de diciembre del 2019 en forma proporcional.

\section{Salario con que se realiza la liquidación}

De conformidad con el artículo 253 del CST, el salario con el que se liquidan las cesantías será tomado con base en el último salario mensual devengado por el trabajador, siempre y cuando no hayan existido variaciones en los últimos tres (3) meses. En caso de que haya variaciones, se tomará como base para la liquidación el promedio del salario devengado en el último año o en todo el tiempo en caso de que fuere inferior a un año.

En caso de que el salario varíe cada año ${ }^{25}$, deberá liquidarse por cada uno de los años trabajados. En este caso, se deben tener en cuenta los días trabajados por cada año para poder realizar la liquidación correspondiente. El salario incluye todos los factores salariales, y no solo el básico devengado por el trabajador; es decir, se le agrega lo que corresponda a

25 Ejemplo sería el trabajador que devengó en el 2016 \$920000, en el 2017 \$1 100000 y en el 2018 \$2 120000 . horas extras, comisiones y demás factores salariales. Si el trabajador tiene derecho a auxilio de transporte, también será tenido en cuenta en las cesantías. Este salario es conocido como el salario base o mensual.

\section{Liquidación}

Teniendo en cuenta que se liquida por cada año trabajado un mes de salario base, y que el auxilio de transporte se toma en cuenta en esta clase de liquidación (solo para quienes tienen derecho a este auxilio), la fórmula que debe ser utilizada para la liquidación de esta prestación social es la siguiente:

Días trabajados $x$

(Salario base + Auxilio de transporte)

\section{EJERCICIO}

Trabajador vinculado desde el 19 de abril del 2017 hasta el 22 de octubre del 2020. Con salario de $\$ 1200000$ en el 2017 y el 2018, y de $\$ 1500000$ en el 2019 y el 2020.

1. Se debe liquidar cada uno de los años laborados con los diferentes salarios:

- Año 2017: 19 de abril al 31 de diciembre:

253 días $\times \$ 1200000$ (salario) / 360:

$\$ 843333,33$

- Año 2018: 360 al trabajar año completo × \$1200000 / 360: \$1200000

- Año 2019: 360 al trabajar año completo x \$1500000 / 360: \$1500000

- Año 2020: Del 01 de enero al 22 de octubre:

- 292 días $\times \$ 1500000$ / 360: \$1216666,67 
PRIMA DE SERVICIOS (ARTS. 306 Y SS. DEL CST)

Esta prestación social surgió con la finalidad de repartir las utilidades de la empresa a los trabajadores, hacerlos parte de esas ganancias en agradecimiento al desempeño de los trabajadores, sin embargo y para evitar que se interprete que solo se reconoce ante las ganancias de los empleadores y no cuando hay perdidas, la Corte Constitucional en sentencia C - 871 de 2014 ha mencionado que debe entenderse como una prestación que compensa a los trabajadores en la prestación de sus servicios, reconociendo el valor social y económico que tienen los trabajadores para la sociedad. Es importante resaltar que esta sentencia tiene relevancia para el derecho laboral, con ella se ha reconocido la prima de servicios a los trabajadores domésticos, lo que posteriormente motivo al legislador en la modificación del Código Sustantivo de Trabajo con la Ley 1788 de 2.016 como se mencionará más en ese sentido, eliminando la exclusión de prima de servicios a los trabajadores domésticos y estableciendo que actualmente todos los trabajadores tienen derecho a esta prestación social.

\section{Liquidación}

La prima de servicios se liquida semestralmente; se debe hacer directamente al trabajador pagando un mes de salario base ${ }^{26}$ por cada año trabajado; se reparte el pago en dos quincenas: una que debe ser pagada antes del 30 de junio y la otra antes del 20 de diciembre. En caso de que el trabajador no alcance a prestar sus servicios hasta las fechas en que se realiza el pago, deberá liquidarse proporcionalmente al tiempo en el que realizó sus labores. La fórmula para liquidar esta prestación social es la misma que la señalada para auxilio de cesantías:

26 Como se ha reiterado, es aquel que incluye el salario básico y otros factores como las comisiones u horas extras.
Días trabajados $\times$ (Salario base + Auxilio de transporte ${ }^{27}$ )

360

El salario por tener en cuenta es el último devengado o el promedio de lo devengado durante el semestre que se vaya a liquidar (de enero a junio, o de junio a diciembre). Un ejemplo lo podemos notar en la tabla 6 , tomada de página web de Gerencie.com:

TABLA 6

Promedio de lo devengado

\begin{tabular}{|c|c|}
\hline Mes & Total devengado \\
\hline Enero & $\$ 2000000$ \\
\hline Febrero & $\$ 2500000$ \\
\hline Marzo & $\$ 1800000$ \\
\hline Abril & $\$ 2300000$ \\
\hline Mayo & $\$ 2000000$ \\
\hline Junio & $\$ 2100000$ \\
\hline Total en los seis meses & $\$ 12700000$ \\
\hline Promedio mensual & $\$ 2116667$ \\
\hline
\end{tabular}

Nota: tomado de Gerencie.com (2020).

Aplicando la fórmula anterior, la prima de servicios se calcula así:

$\$ 2116667 \times 180 \div 360=\$ 1058333$

\section{INTERESES DE CESANTÍAS LEY 52 DE 1975}

Los intereses a las cesantías son una prestación subsidiaria derivada del auxilio de cesantías; consisten en otorgar un 12\% anual del valor acumulado por auxilio de cesantías en cada año. Es un pago que se reconoce directamente al trabajador.

27 Como se ha explicado, este se incluye siempre que el trabajador devengue menos de dos salarios mínimos como salario básico. 


\section{Forma, monto y plazo de pago}

Los intereses a las cesantías se pagan al trabajador de forma directa en diferentes eventos:

- Por cada año trabajado si hay continuidad y este fue trabajado en forma completa (ejemplo: desde el 1 de enero al 31 de diciembre).

- Por la proporción en que haya trabajado cuando existe continuidad y el primer año trabajado es inferior a uno completo (ejemplo: ingresó desde abril y continúa prestando los servicios).

- De forma proporcional cuando termina el contrato sin completar el periodo de un año completo (ejemplo: terminó contrato en septiembre).

El monto para cancelar intereses por cada año es del 12\% sobre el valor que fue pagado de cesantías cuando prestó sus servicios por todo el año; en caso de que el trabajador no haya estado vinculado el año completo, deberán pagarse estos intereses de forma proporcional al tiempo en que el trabajador haya prestado sus servicios.

El plazo para el pago de esta prestación social es el 31 de enero del año siguiente a su causa; es decir, en caso de que el trabajador haya estado vinculado desde el 01 de enero de 2018 y aún siga vigente su vínculo al 18 de julio de 2019, el pago de los intereses debió realizarse máximo hasta el 31 de enero de 2019; se sigue liquidando de esta forma por cada año en que continúe la relación laboral. Cuando el contrato de trabajo finaliza, deben liquidarse en proporción al tiempo trabajado, para lo cual se utiliza la siguiente fórmula:

Salario base o mensual $\times$

Días trabajados $\times 0,12$

\section{EJERCICIOS PRÁCTICOS}

\section{Primer caso hipotético}

El señor Adriano Ríos celebró un contrato de trabajo a término fijo con Carlos Casas. Este vínculo inició el 15 de diciembre de 2018 y finalizó el 9 de junio de 2021. La remuneración pactada fue por valor de $\$ 1.800 .000$ mensuales, recibía además $\$ 120000$ mensuales relacionados con horas extras y $\$ 70000$ de propinas.

\section{Preguntas:}

1. ¿Cuál es el valor de auxilio de cesantías por el tiempo trabajado?

2. ¿Cuál es el valor de vacaciones por el tiempo trabajado?

3. ¿Cuál es el valor de intereses sobre cesantías por el tiempo trabajado?

\section{Solución:}

Para desarrollar el ejercicio, seguiremos los siguientes pasos:

1. Realizar una resta laboral: teniendo en cuenta las fórmulas para estos ejercicios, es necesario conocer el número total de días trabajados. Lo recomendable es realizar la resta laboral, como se explica en los siguientes pasos:

1.1. Se coloca la fecha mayor en la parte superior y la fecha menor en la parte inferior; la fecha mayor es la más actual (la del año más grande); se escribe primero el dato de año, luego mes y día; se comienza restando de derecha a izquierda, primero días, luego meses y posteriormente años:

$\begin{array}{lcc}\longleftarrow \text { Año } & \text { Mes } & \text { (Orden para el ejercicio) } \\ 2021 & 06 & 09 \\ 2018 & 12 & 15\end{array}$


En este ejercicio se debe realizar préstamo de días al valor vecino debido a que el número superior es más bajo que el inferior ${ }^{28}$. Cuando hacemos estos préstamos, debemos tener en cuenta que los meses prestan 30 días al factor días y los años prestan 12 meses al factor meses. No se puede olvidar el valor que estaba previamente escrito en el ejercicio, y este último hay que sumarlo al préstamo. La solución sería así:

\begin{tabular}{ccc} 
Año & Mes & Día \\
$2021^{29}$ & $17^{30}$ & $39^{31}$ \\
2018 & 12 & 15 \\
\hline 02 & 0 & $24(+1)$
\end{tabular}

Después de obtener estos resultados, como lo que se requiere es un cálculo en días, hay que convertir los meses a días y los años también. Para esto hay que tener en cuenta que en los ejercicios de derecho laboral un mes equivale a 30 días y un año a 360 días. Para finalizar, se suman los días de esas operaciones, se desarrolla de la siguiente forma:

$\begin{array}{ll}\text { Años: } & 2 \times 360=720 \\ \text { Meses: } & 5 \times 30=150 \\ \text { Días: } & 24+1=25\end{array}$

Total de días: 895 Días

Con este valor ya puede terminarse el ejercicio ubicando los datos en las fórmulas de cada prestación social y de las vacaciones:

28 Siempre que en la resta laboral el número superior sea más alto que el inferior se debe hacer el préstamo explicado.

29 Queda en 2017 teniendo en cuenta el préstamo que le hace a los meses.

30 El ejercicio inicial tenía un 6; al prestar un mes a los meses, quedaba en un $5, y$ al necesitar también un préstamo de un año, queda en 17 ( 5 que había en meses, más doce meses que presta el año].

319 que teníamos más 30 días del mes prestado.
1. Vacaciones:

Salario básico $\times$ Días trabajados

720

$\$ 1.800 .000^{32} \times 895 / 720=\$ 2.237 .500$

\section{Auxilio de cesantías}

Salario base ${ }^{33} \times$ Días trabajados

360

$\$ 2.008 .211^{34} \times 895 / 360=\$ 4.992 .635,68^{35}$

\section{Intereses de cesantías}

Salario base ${ }^{36} \times$ Días trabajados $\times 0,12$

360

$\$ 2.008 .211 \times 895 \times 0,12 / 360=\$ 599.116,28$

Segundo caso hipotético: salarios variables en cada año

El señor Eligio celebró un contrato de trabajo a término indefinido con Silvestre Dangond. Este vínculo inició el 21 de mayo de 2017 y finalizó el 2 de julio de 2019. La remuneración pactada fue por los siguientes valores:

En el 2017: \$1400000

En el 2018: \$1580000

En el 2019: \$1900000

32 Se escribe solo el salario básico, teniendo en cuenta los conceptos señalados.

33 Al ser salario mensual, se toman en cuenta todos los factores que sean salariales, y si tiene derecho, también el auxilio de transporte, que en el 2018 era de $\$ 88211$.

34 Se sumaron $\$ 900000$ del salario básico, $\$ 120000$ de horas extras al ser factor salarial y $\$ 88211$ de auxilio de transporte; las propinas, como se ha mencionado, no constituyen salario.

35 La prima de servicios correspondería a este mismo valor; recordar que la fórmula para liquidar es la misma.

36 Al ser salario base, se toman en cuenta todos los factores que sean salariales, y si tiene derecho también, el auxilio de transporte, que en el 2018 era de $\$ 88211$. 
En el 2019, además de la remuneración, se pactaron comisiones por ventas. Eligio ganó cada mes estas comisiones por valor de $\$ 95000$ mensuales; además, le reconocieron viáticos de transporte mensuales por valor de \$110000 y le pagaron también mensualmente viáticos de alojamiento y de manutención por valor de $\$ 220000$.

\section{Preguntas:}

1. ¿Cuál es el salario base de Eligio en el 2019?

2. ¿Cuál es el valor de prima de servicios por el tiempo trabajado?

3. ¿Cuál es el valor de vacaciones por el tiempo trabajado?

\section{Solución:}

1. El salario mensual corresponde a la suma de todo lo que sea factor salarial a la luz de los artículos 127 y ss. del cst. En este caso, es salario base o mensual. La remuneración pactada en el 2019 es de $\$ 1900000$, las comisiones pagadas por valor de $\$ 95000$ y los viáticos de manutención y alojamiento pagados por valor de $\$ 220000$ mensuales. Es decir, el salario base o mensual de Eligio es de $\$ 2215000$.

2. Para las preguntas dos y tres, se requiere conocer el número de días trabajados por cada año. Teniendo en cuenta que el salario fue diferente, se recomienda continuar con método de resta laboral para ir practicando y ya luego ubicar los valores en las correspondientes fórmulas:

Año 2017: trabajó desde el 21 de mayo hasta la finalización de este año. Es importante tener en cuenta que en los ejercicios de derecho laboral todos los meses los tomamos por 30 días:

\begin{tabular}{ccc} 
Año & Mes & Día \\
2017 & 12 & 30 \\
2017 & 05 & 21 \\
\hline 0 & $07 \times 30$ & $09(+1)$ \\
\multicolumn{2}{c}{$210+10=\mathbf{2 1 9}$ Días }
\end{tabular}

Año 2018: para este año, al trabajarlo completo, no hay necesidad de hacer la resta laboral, son 360 días.

Año 2019: trabajó desde el 01 de enero hasta el 2 de julio:

$\begin{array}{ccc}\text { Año } & \text { Mes } & \text { Día } \\ 2019 & 07 & 02 \\ 2019 & 01 & 01\end{array}$

$06 \times 30 \quad 1(+1)$
$180+2=182$ Días

Con la contabilización de los días y con el conocimiento del salario base, ya puede terminarse el ejercicio ubicando los datos en las fórmulas de cada prestación social y de las vacaciones:

\section{Vacaciones:}

Salario básico × Días trabajados

720

Año 2017:

$\$ 1400000 \times 219$

720

Año 2018:

$\frac{\$ 1580000 \times 360}{720}=$

Año 2019:

$\$ 1900000 \times 182$ 
Prima de servicios

Salario base ${ }^{37} \times$ Días trabajados

360

Año 2017:

$$
\$ 1400000+83140^{38} \times 219
$$

Año 2018:

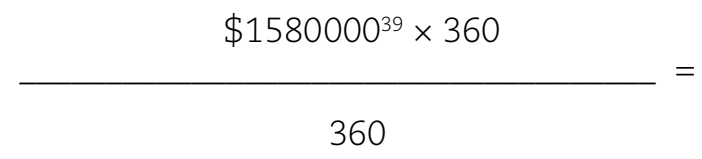

Año 2019:

$\$ 2215000^{40} \times 182$ $=$

37 Al ser salario base, se toman en cuenta todos los factores que sean salariales, y si tiene derecho, también el auxilio de transporte, que en el 2018 era de $\$ 88211$.

38 En este año se debe sumar el auxilio de transporte para la liquidación, teniendo en cuenta que el salario básico es inferior a dos salarios mínimos del año 2017, el SMLMV de este año fue de $\$ 737>1$ ?

\section{REFERENCIAS}

39 En este caso no se suma auxilio de transporte, debido a que el salario supera los dos salarios mínimos del 2018, que estaba fijado en $\$ 781242$.

40 Se toma en cuenta el salario base ya identificado, no se suma auxilio de transporte porque el salario básico supera dos salarios mínimos.

Arenas Monsalve, G. (2008). El derecho colombiano de la seguridad social (2. a ed.). Legis.

Congreso de la República de Colombia. (1950). Decreto 2663 de 1950, Código Sustantivo del Trabajo. https:// bit.ly/3v6xwZx

Congreso de la República de Colombia. (1959). Ley 15 de 1959, por la cual se reconocen intereses anuales a las cesantías de los trabajadores particulares. https://bit.ly/3mLobm5

Congreso de la República de Colombia. (1975). Ley 52 de 1975, por la cual se reconocen intereses anuales a las cesantías de los trabajadores particulares. https://bit.ly/3Dw10TD

Congreso de la República de Colombia. (1990). Ley 50 de 1990, por la cual se introducen reformas al Código Sustantivo del Trabajo y se dictan otras disposiciones. https://bit.ly/2X2hIKO

Congreso de la República de Colombia. (1993). Ley 100 de 1993, por la cual se crea el sistema de seguridad social integral y se dictan otras disposiciones. https://bit.ly/3arOVUH

Congreso de la República de Colombia. (2000). Ley 583 de 2000, por la cual se modifican los artículos 30 y 9 del Decreto 196 de 1971. https://bit.ly/2YAaAWu

Congreso de la República de Colombia. (2015). Ley 1755 de 2015, por medio de la cual se regula el Derecho Fundamental de Petición y se sustituye un título del Código de Procedimiento Administrativo y de lo Contencioso Administrativo. https://bit.ly/3Bt6JZT

Congreso de la República de Colombia. (2016). Ley 1788 de 2016, por medio de la cual se garantiza el acceso en condiciones de universalidad al derecho prestacional de pago de prima de servicios para los trabajadores y trabajadoras domésticos. https://bit.ly/2X3hsv3

Congreso de la República de Colombia. (2018). Constitución Política de Colombia. Bogotá: Legis.

Corte Constitucional Colombiana. (2006). Sentencia C-823 de 2006, M. P.: Rodrigo Escobar Gil. https://bit. ly/3oQ4rQX 
Corte Constitucional Colombiana. (2006). Sentencia C- 871 de 2.014, M.P. Maria Victoria Calle Correa. https:// www.corteconstitucional.gov.co/relatoria/2014/C-871-14.htm

Corte Suprema de Justicia, Sala de Casación Laboral. (2011). Sentencia 36035 de 2001, M. P.: Luis Gabril Miranda Buelvas. https://vlex.com.co/vid/552629726

Corte Suprema de Justicia, Sala de Casación Laboral. (2018). Sentencia 40374 de 2018, M. P.: Rigoberto Echeverri Bueno. https://bit.ly/306vxZN

Corte Suprema de Justicia, Sala de Casación Laboral. (2018). Sentencia 57903 de 2018, M. P.: Giovanni Francisco Rodríguez Jiménez. https://bit.ly/2YO5Z3j

Cortés Hernández, O. I. (2007). Derecho de la seguridad social (3.ª ed.). Bogotá: Ediciones El Profesional.

Gerencie. (2020, 2 de mayo). Prima de Servicios. https://www.gerencie.com/prima-de-servicios.html

Gerencie. (2021, 22 de junio). Auxilio de Transporte. https://www.gerencie.com/auxilio-de-transporte.html

Gerencie. (2021,7 de enero). Valor Histórico del salario mínimo en Colombia. https://www.gerencie.com/historico-del-salario-minimo-en-colombia.html

Presidencia de la República de Colombia. (1991). Decreto 1127 de 1991, por el cual se reglamentan los artículos 3 y 21 de la Ley 50 de 1990. https://bit.ly/3luwfZ4

Presidencia de la República de Colombia. (1991). Decreto 2591 de 1991, por el cual se reglamenta la acción de tutela consagrada en el artículo 86 de la Constitución Política. https://bit.ly/3BxLRAx

Ridulfo, E. y Herrera, S. (2018). El control de legalidad y el principio de revisión de los actos administrativos. Opinión Jurídica, 1(1), 59-72. https://bit.ly/3v21deg

Vargas, C. M. (2010). Derecho laboral: manual teórico práctico. Ibáñez. 


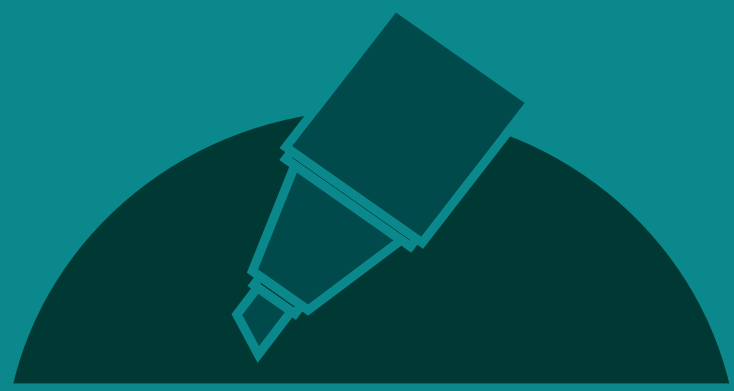

Guías

prácticas 